\title{
Isolation and identification of Amycolatopsis sp. strain 1119 with potential to improve cucumber fruit yield and induce plant defense responses in commercial greenhouse
}

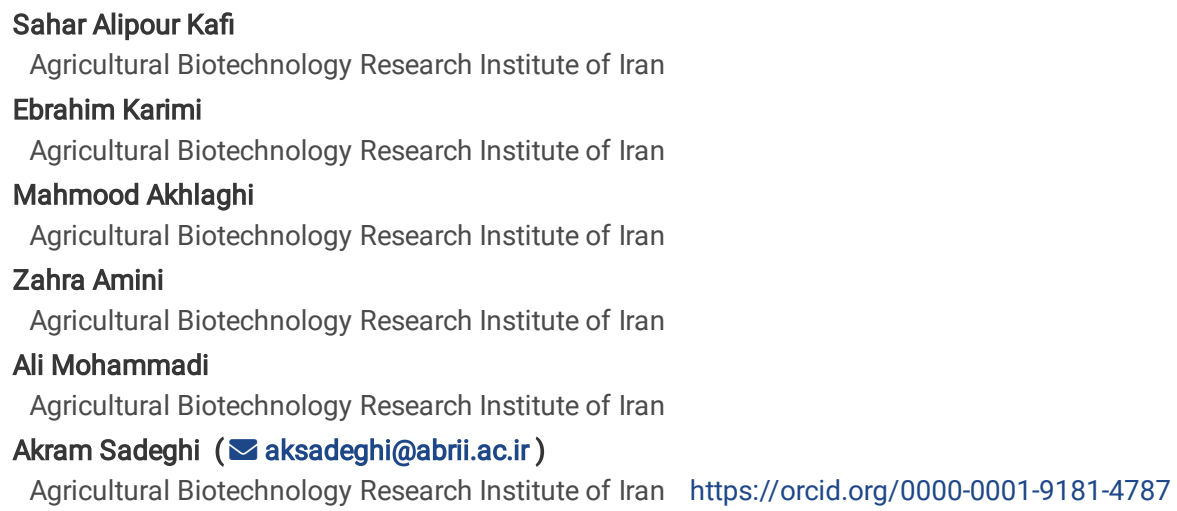




\section{Abstract}

\section{Background and aims}

The application of chemical fungicides is the first strategy to control plant fungal diseases. This approach is highly polluting for the environment and affects human health. Artificial introduction of beneficial rhizobacteria into the soil can be an economical and practical way to control phytopathogenic fungi in commercial greenhouses. Here, we recount the travel of a rare Actinomycete (Amycolatopsis strain 1119) from a maize field to a commercial cucumber greenhouse.

\section{Methods and results}

Culturable bacteria from rhizosphere and bulk soils of dicot and monocot crops were isolated and screened. About $20 \%$ of the representative colonies showed Actinomycetes appearance. 106 Actinomycetes that had antagonistic activity against Phytophthora capsici and were able to produce IAA were selected for further analysis. Two Streptomyces strains (432 and 615) and 2 Amycolatopsis strains (3513 and 1119) that showed a positive effect on plant growth in greenhouse conditions were selected to evaluate for biocontrol potential. Strains $432,3513,615$ and 1119 controlled incidence of the damping-off by $65 \%$, $42 \%, 83 \%$ and $100 \%$ respectively. Application of strain 1119 under commercial greenhouse conditions resulted in an increase in fruit yield (20\%) and a decrease in fruit nitrate content (70\%). Increased antioxidant enzymes activity and increased $L O X$ and $A P X$ transcription and also, increased expression of two genes PR1-1a and GLU(SAR genes) showed that strain 1119 could induce both ISR and SAR in cucumber without pathogen exposure.

\section{Conclusion}

Our results demonstrate that the Amycolatopsis strain 1119, has a great potential to enter the market as a bio-stimulator.

\section{Introduction}

At present, the application of chemical fungicides is the first strategy to control and manage plant fungal diseases. This approach is highly polluting and has consequences on the development of resistant strains of phytopathogenic fungi (Café-Filho and Ristaino, 2008). Disease-suppressive soils are defined as soils in which, despite the presence of the virulent pathogens, disease incidence occurs at a low rate (Kinkel et al., 2011). Beneficial soil rhizobacteria (BSRs), including some species of Actinomycetes, non-pathogenic Pseudomonas and Bacillus are consistently associated with disease suppression (Schlatter et al., 2017). The potential of BSRs to suppress plant root fungal diseases was reported in many studies (Islam et al., 2016; Karimi et al., 2012; Rangarajan et al., 2003; Abbasi et al., 2020). Exudate of the plant root is the main source of the nutrients in the rhizosphere and attracts BSRs to themselves selectively (Lareen et al., 2016). Microbial communities in the root environment can be deliberately manipulated to increase plant health and yield. The development of methods for manipulation of the rhizobacterial communities to transfer disease suppressiveness to a non-suppressive soil is a promising way to reduce chemical fungicides. In this regards, several studies have been done to examine the effect of crop rotation (Niu et al., 2016), application of organic fertilizers (Zaller et al., 2004), bio-fertilizers containing living BSRs (Vessey, 2003) and bulk soil (Weller et al., 2002) on the suppressiveness properties of soil. Based on the results of these researches, manipulation of the cropping system and artificially introduction of BSRs into the soil, as bio-fertilizer or biocontrol agents, are two economic and practical methods to control phytopathogenic fungi in crop fields.

The Actinomycetes is a phylum of Gram-positive bacteria and can be found in bulk and rhizosphere soil (Sharma and Salwan, 2018). Streptomyces is a wellknown genus of Actinomycetes. Diverse species of Streptomyces produce more than $70 \%$ of the antibacterial and antifungal components are used in medicine, veterinary and agriculture (Landwehr et al., 2016). Also, Streptomyces produce many secondary metabolites, including volatile compounds (Cordovez et al., 2015) and extracellular hydrolytic enzymes that are active in fungal cell wall degradation (Brzezinska et al., 2014; Sadeghi et al., 2017). Cordovez et al. (2015) studies showed that Streptomyces species were the most dynamic and abundant (70\% of the isolates) in a Rhizoctonia suppressive soil. Although there are many studies which present control destructive plant pathogens by Streptomyces species (Viaene, et al., 2016), the biocontrol potential of non-Streptomyces Actinomycetes are rarely reported (El-Tarabily et al., 2006; Mingma et al., 2014; Tanvir et al., 2014). Furthermore, little is known about the diversity and distribution of the antagonistic Streptomyces or non-Streptomyces Actinomycetes among the rhizosphere soil of different crops. Davelos et al. (2004) investigated the diversity of the antagonistic Streptomyces in natural habitat (non-agricultural soil). They found that there is a considerable variation in culturable Streptomyces communities among different locations of a habitat. Also, it is reported that the density of the antagonistic Streptomyces associated with rhizosphere soil, significantly differed among species of prairie plants (Bakker et al., 2013). A more detailed study showed that diversity, phylogenetic composition, and pathogen inhibition activity among Streptomyces communities of non-agricultural and agricultural soils were similar and only intensity and breadth of inhibitory activities differed among phylogenetic groups (Bakker et al., 2010). Niu et al. (2016) have reported the importance of crop plants as a key factor in determining function and genetic diversity of the antagonistic BSRs. Their culture-independent study showed that only tobacco-maize rotation cropping system but not lily or turnip, decrease the incidence of tobacco bacterial wilt.

Actinomycetes especially Actinomycetales, Streptomycetales and Pseudonocardiaceae are playing fundamental roles in growth-promotion and biological control of insect pests and pathogens which cause damage to grain crops such as leguminous and cereals (Gopalakrishnan et al., 2019).

Amycolatopsis, is a genus of Actinomycetales, within the family Pseudonocardiaceae. They are Gram-positive filamentous bacteria with a high GC content in their genomes (Tang et al., 2010).

To the best of our knowledge the genus Amycolatopsis, contains 87 recognized species and 4 subspecies (https://lpsn.dsmz.de/genus/amycolatopsis). Unfortunately, the significance of this genus in agriculture is not well known. 
The objectives of the present research were to (1) select and characterize Actinomycetes isolates from bulk and rhizosphere soil of different monocot and dicot crops fields, with ability to inhibit the growth of the most important fungal pathogens that cause damping-off and wilt in cucumber (2), detect hydrolytic enzyme activity and PGP (plant growth promotion) traits of the antagonistic isolates, (3) investigate the PGP effect of selected strains in greenhouse condition (4), evaluate the biocontrol of Phytophthora capsici, the causal agent of cucumber damping-off by PGP strains under greenhouse conditions and (5), evaluate the effect of the most promising strain (Amycolatopsis sp. strain 1119) on yield, fruit quality and molecular and cellular defense mechanisms of cucumber plants grown under commercial greenhouse conditions.

\section{Methods And Results}

Isolation, cultivation, and maintenance of Actinobacteria isolates

Wheat (Triticum aestivum L.), maize (Zea mays L.), tomato (Solanum lycopersicum L.) and cucumber (Cucumis sativus L.) roots with adhering soil were harvested from healthy plants grown in individual farms located in Alborz province, Iran in 2015. Three farms were considered for each crop and three root samples were randomly collected from each farm. Also, three soil samples, without plant residues (assigned as bulk soil) were randomly collected from margins ( 5 meters away from the last row of plants) of each farm. Excess soils were removed following gentle shaking of the roots and the soils that remained attached to the roots were considered as rhizosphere soils. In total, 36 rhizosphere and 36 bulk soil samples were collected. For isolation of Actinobacteria, $2 \mathrm{~g}$ soil was diluted in $100 \mathrm{ml}$ of sterile saline solution $(0.9 \% \mathrm{NaCl})$ and shaken for $30 \mathrm{~min}$. Three serial dilutions (1:100, 1:1000 and 1:10000) were prepared using sterile saline solutions in a total volume of $1 \mathrm{ml}$. An aliquot of $0.1 \mathrm{ml}$ of each dilution was plated on water agar (18 $\mathrm{g} / \mathrm{l} \mathrm{pH} 7.2)$. The plates were incubated at $29^{\circ} \mathrm{C}$, for 7 days. Representative colonies were selected and streaked on new plates of MYA medium (containing $10 \mathrm{~g} / \mathrm{l}$ malt extract, $4 \mathrm{~g} / \mathrm{l}$ yeast extract, $4 \mathrm{~g} / \mathrm{l}$ glucose and $18 \mathrm{~g} / \mathrm{l}$ agar, adjusted to $\mathrm{pH} 7.2$ ) at $29^{\circ} \mathrm{C}$.

Antifungal activity

The procedure of Yuan and Crawford (1995) was used to examine the antagonistic activity of the Actinobacteria isolates against five plant pathogens including Phytophthora drechsleri, P. capsici, Pythium ultimum, Rhizoctonia solani and Fusarium oxysporum. A sterile needle was used to culture one individual bacterial cfu in the center of PDA (potato dextrose agar) plate. Plugs from the growing edge of each pathogen fresh culture were placed on the two sides of the PDA plate. Plates were incubated at $23^{\circ} \mathrm{C}$ for 5 days. The pathogen $P$. capsici strain sa (GenBank accession number MG670447) was kindly provided by Dr. Azimi, Iranian Research Institute of Plant Protection (IRIPP), Tehran, Iran. The growth inhibition percentage was calculated using the formula $\mathrm{n}$ $=(a-b) / a \times 100$, where ' $n$ ' is the growth inhibition percentage, ' $a$ ' is the fungal growth radius of a control culture (in cm) and ' $b$ ' is the distance of the pathogen growth in the direction of bacteria (in $\mathrm{cm}$ ).

Cellulase activity

Carboxymethyl cellulase (CMCase) activity was determined by Mandels-Reese medium with carboxymethyl cellulose (CMC) as the sole carbon source (Majidi et al. 2011). The bacteria were grown on $\mathrm{CMC}$ agar containing $0.4 \mathrm{~g} / \mathrm{I} \mathrm{KH}_{2} \mathrm{PO}_{4}, 0.02 \mathrm{~g} / \mathrm{l} \mathrm{CaCl}_{2}, 0.02 \mathrm{~g} / \mathrm{l} \mathrm{NaCl}, 0.02 \mathrm{~g} / \mathrm{l} \mathrm{FeSO}$. $7 \mathrm{H}_{2} \mathrm{O}, 2.5 \mathrm{~g} / \mathrm{l} \mathrm{CMC}$, and $15.0 \mathrm{~g} / \mathrm{l}$ agar. The $\mathrm{pH}$ was adjusted to 7.2 with $1 \mathrm{M} \mathrm{NaOH}$. The $\mathrm{CMC}$ agar plates were incubated at $29^{\circ} \mathrm{C}$ for 7 days to allow the secretion of cellulase. At the end of the incubation, to visualize the hydrolysis zone, the agar medium was flooded with an aqueous solution of Congo red ( $1 \mathrm{mg} / \mathrm{ml})$ for $20 \mathrm{~min}$. The Congo red solution was then poured off, and the plates were further treated by flooding with $1 \mathrm{M} \mathrm{NaCl}$ for $15 \mathrm{~min}$. To indicate the cellulase activity, the diameter of a clear zone around each colony was measured. The ratio of the clear zone diameter to colony diameter was calculated and recorded as cellulase activity.

Chitinase activity

Chitinase production was determined according to the method of Hsu and Lockwood (1975). Bacterial isolates were grown on chitin agar containing $0.4 \%$ colloidal chitin and 1.5\% agar adjusted to $\mathrm{pH}$ 7.2. The colloidal chitin was prepared according to Berger and Reynolds (1958). Plates incubated for 5 days at $29{ }^{\circ} \mathrm{C}$. The ability of chitinase production was shown by a clear halo around colonies. The ratio of the clear zone diameter to colony diameter was calculated and recorded.

Siderophore production

Siderophore production was evaluated according to Alexander and Zuberer (1991) on Chrome Azurol agar (CAS) medium. The CAS agar medium was prepared and distributed in Petri dishes then bacterial isolates were spot-seeded onto the center of the plate and incubated at $29{ }^{\circ} \mathrm{C}$ for 7 days. The colonies producing orange halo were considered as siderophore-producing isolates. After three days, the ratio of the halo zone diameter to colony diameter was calculated and recorded.

Phosphate-solubilizing activity

Pikovskaya's medium (PVK) was used to measure calcium phosphate $\left[\mathrm{Ca}_{3}\left(\mathrm{PO}_{4}\right)_{2}\right]$-solubilizing activity. Sterilized PVK medium with pH 7.2 was poured into the sterilized Petri plates. After solidification of the media, bacterial isolates were spot-seeded onto the center of the plate and incubated at $29{ }^{\circ} \mathrm{C}$ for 7 days. Solubilization index was evaluated according to the ratio of the clear zone diameter to colony diameter (Soltani et al., 2010).

Presumptive nitrogen fixation (free-living putative diazotrophs)

The ability of the isolates to growth on solid nitrogen-free medium (NFM) was evaluated according to Dahal et al. 2017. The bacteria were grown on NFM containing $\mathrm{K}_{2} \mathrm{HPO}_{4}(0.2 \mathrm{~g} / \mathrm{l}), \mathrm{KH}_{2} \mathrm{PO}_{4}(0.5 \mathrm{~g} / \mathrm{l}), \mathrm{MgSO}_{4} .7 \mathrm{H}_{2} \mathrm{O}(0.2 \mathrm{~g} / \mathrm{l}), \mathrm{FeSO}_{4} .7 \mathrm{H}_{2} \mathrm{O}(0.1 \mathrm{~g} / \mathrm{l}), \mathrm{Na}_{2} \mathrm{MoO}_{4} .2 \mathrm{H}_{2} \mathrm{O}(0.005 \mathrm{~g} / \mathrm{l}), \mathrm{NaCl}(0.2 \mathrm{~g} / \mathrm{l}), \mathrm{glucose}(10 \mathrm{~g} / \mathrm{l})$ and 
$15.0 \mathrm{~g} / \mathrm{l}$ agar. After 7 days incubation at $29^{\circ} \mathrm{C}$, the growth of each isolate was evaluated and compared with growth on the MYA medium as a positive control.

Indole-3-acetic acid (IAA) productionThe production of IAA was determined based on the method described by Patten and Glick (2002). Actinobacteria isolates were inoculated in $100 \mathrm{ml}$ flasks containing $25 \mathrm{ml} \mathrm{TSB}$ (Tryptic soy broth) medium supplemented with $2 \mathrm{mg} / \mathrm{ml}$ L-tryptophan at $29^{\circ} \mathrm{C}$ for 5 days on a rotary shaker $(150 \mathrm{rpm})$. Bacterial cells were then collected by centrifugation at 10,000 g for $15 \mathrm{~min}$. Two $\mathrm{ml}$ of Salkowsky reagent was added to one ml of the supernatant and absorbance of the solution was read at $535 \mathrm{~nm}$ in a UV-Vis Spectrophotometer (Cary 300). The IAA concentration was determined using a standard IAA (Sigma-Aldrich) calibration curve.

\section{Genotypic characterization}

Isolation of DNA was performed according to the method of Tripathi and Rawal (1998). PCR amplification of the 16S rRNA gene was carried out as described by Chun and Goodfellow (1995). The almost-complete 16S rRNA gene sequences (1400 nt) were deposited in the GenBank database under the accession numbers MG995004 (strain 407), MG995003 (strain 405), MN888928 (strain 432), MN888932 (strain 515), MN888935 (strain 3637 ), MG984768 (strain 3415 ), MH266469 (strain 3513), MG984616 (strain 1119), MG995001 (strain 1118), MG995005 (strain 1331), MN493628 (strain 1317$),$ MN888939 (strain 614 ) and MN888940 (strain 615). The sequences aligned manually with corresponding sequences of available Actinobacteria species drawn from the GenBank, EMBL and DDBJ databases by using BLAST (Altschul et al. 1997). Phylogenetic tree was constructed using the MEGA 5.0 software package (Tamura et al. 2011) based on the method of neighbor-joining. Bootstrap analyses were used to evaluate the stability of relationships based on 1000 resampling.

\section{Greenhouse experiments}

Experiment 1: evaluation of plant growth promotion

Surface sterilized cucumber seeds ( $C$. sativus L. Soltan cultivar) were pre-germinated at room temperature for $72 \mathrm{~h}$. Thirty-five seedlings were placed into a 35 cell plug tray $(25 \times 25 \times 2.5 \mathrm{~cm}$ deep), with one seedling occupying each cell. The trays were filled with a sterile mixture of field soil and peat moss (1:2). For bacterial treatments, bacterial spore suspension in sterile saline solution was added to autoclaved sand and final cfu/g adjusted to $10^{6}$. A mixture of sand and sterile saline solution was used as untreated control. Bacterial formulation (one-gram sand/seedling) was added to the mixture of soil and peat moss just before filling the trays. The trays were kept in a greenhouse at $27^{\circ} \mathrm{C}$ and $16 \mathrm{~h} / 8 \mathrm{~h}$ brightness/darkness. Soil irrigated with tap water and drain water from each tray was added to the soil. There were four replicates (4 trays) of each bacterial treatment and untreated control and the experiment were arranged in a randomized complete design (CRD). The seeds were watered every 2 days. To evaluate the effects of the bacterial treatment on plant growth, dry and fresh weight of root and shoot and plant height were measured 30 days after planting.

Experiment 2: evaluation of biocontrol activity

The PGPR isolates were selected based on the results of the first experiment and the second experiment was repeated as experiment 1 with 8 replications (8 trays) for each bacterial treatment and control.

After 14 days of bacterial treatment, trays were divided into two groups inoculated and uninoculated. Cucumber seedlings in the inoculated group were inoculated artificially with the pathogen. A plug of the P. capsici fresh culture on PDA media was positioned on the surface of each cell (at a distance of 0.5 $\mathrm{cm}$ from the crown) and disease signs were monitored daily. The inoculated seedlings were checked daily and the number of diseased seedlings (with a thin and brown stem or completely death) was recorded. Final disease incidence was determined 16 days after inoculation based on total diseased seedlings percentage. At the end of the experiment (30 days after planting) the plants of the uninoculated group were harvested and the fresh and dry weight of roots and shoots were measured.

Experiment 3: Performance evaluation of strain 1119 at the commercial greenhouse conditions

Greenhouse experiments were conducted in spring 2019 in a 1250 square meter soil-based typical solar commercial greenhouse located in Mohammadabad-e Arab a village in Varamin County, Tehran Province, Iran. The experimental design was a randomized complete block (RCB) with 2 treatments and four replications. Each replicate was a 20-m-long row containing 30 plants. Treatments consisted strain 1119 and untreated as control. Greenhouse soil preparation, use of animal manure, seed ( $C$. sativus L. Soltan cultivar) germination and transplanting in the soil, irrigation, light and temperature management, weed removal, use of fungicide and pest management were carried out according to the typical methods in the area. The deficiency of minor elements was identified by the specialist during the plant growth and development and was treated with foliar spray. Three macronutrients of potassium (K), phosphate (P) and nitrogen $(\mathrm{N})$ were added periodically to the irrigation water according to the expert opinion. Ten days after plants transfer to soil, treatment with 1119 was done. Fifteen days after treatment, the leaves of four plants from each replicate were harvested and pooled, frozen in liquid nitrogen and kept at $-80{ }^{\circ} \mathrm{C}$ for more analysis. One hundred days after treatment, 15 times (with a two-day interval), fruits were harvested and their fresh weight was recorded.

Fruit quality, dry weight percent and content of sugar and nitrate

To determine the percentage of dry weight, $100 \mathrm{~g}$ of the fresh cucumber (4 fruits were selected from each replicate and then $25 \mathrm{~g}$ of each fruit was pooled) was cut into $5 \mathrm{~mm}$ pieces and dried in an oven at $55^{\circ} \mathrm{C}$. For sensorial evaluation, the samples were presented to 40 untrained panelists, $(25$ males and 15 females in range of 24-50 years old). Each participant was asked to evaluate fruits by scoring characteristics (bitterness, fragility, aroma, juiciness, appearance, flavor and overall acceptance) with grades ranged from 1 to 5 , where $1=$ weakly accepted and $5=$ excellent quality

To estimate total soluble sugar, $200 \mathrm{mg}$ of frozen fruit was added to a centrifuge tube and homogenized with $1.5 \mathrm{~mL}$ of $80 \%$ ethanol solution in a vortex for 50 s. The sample was centrifuged at $5000 \times \mathrm{g}$ for $10 \mathrm{~min}$ and the supernatant was put in an oven at $50^{\circ} \mathrm{C}$ to evaporate ethanol. Respectively, $10 \mathrm{~mL}$ of deionized water, $0.47 \mathrm{~mL}$ of $0.3 \mathrm{~N} \mathrm{BaOH}$ and $0.5 \mathrm{~mL}$ of $5 \% \mathrm{Zn}\left(\mathrm{SO}_{2}\right)_{2}$ solution was added to the sample. The tube containing sample was centrifuged at $5000 \times \mathrm{g}$ for 10 
min. Phenol $(5 \%, 0.5 \mathrm{~mL})$ and sulphuric acid $(98 \%, 2.5 \mathrm{~mL})$ were added to $1 \mathrm{~mL}$ of the supernatant. After 45 min, the absorbance of solutions was read at 485 nm using a spectrophotometer (Cary 300, Agilent, USA). Soluble sugar content was calculated using glucose as a standard curve (Dubois et al., 1956).

To evaluate the nitrate content, $100 \mathrm{mg}$ of frozen fruit was added to a centrifuge tube and homogenized with $1 \mathrm{~mL}$ of deionized water and placed in BainMarie at $45^{\circ} \mathrm{C}$ for $60 \mathrm{~min}$. The homogenate was centrifuged at $8000 \times \mathrm{g}$ for $10 \mathrm{~min}$ and $100 \mu \mathrm{L}$ of supernatant was mixed to $400 \mu \mathrm{L}$ deionized water, then 100 $\mu \mathrm{L}$ of the mixture was added to $400 \mu \mathrm{L}$ salicylic acid (5\% salicylic acid in sulfuric acid). After $20 \mathrm{~min}, 9.5 \mathrm{~mL} \mathrm{NaOH} 2 \mathrm{M}$ was added and the absorbance of solution was read at $410 \mathrm{~nm}$ using the spectrophotometer. Potassium nitrate $\left(\mathrm{KNO}_{3}\right)$ was used to prepare a standard curve (Cataldo et al., 1975).

Protein, MDA (malondialdehyde) and $\mathrm{H}_{2} \mathrm{O}_{2}$ content and antioxidant enzymes activity

Frozen leaves (500 mg fresh weight) were homogenized in Na-Pi buffer containing $10 \mathrm{mg}$ polyvinylpyrrolidone. The homogenate was centrifuged at $8000 \times \mathrm{g}$ for $30 \mathrm{~min}$ at $4^{\circ} \mathrm{C}$ and the supernatant was used as a crude enzyme extract (CEE) to determine total protein content (Bradford, 1976) and activity of ascorbate peroxidase (APX: EC 1.11.1.11), catalase (CAT: EC 1.11.3.6) and peroxidase (POX: EC 1.11.1.7). To measure CAT activity, a reaction mixture consisting of 100 $\mathrm{mM}$ potassium phosphate buffer ( $\mathrm{pH}$ 7), deionized water and $70 \mathrm{mM} \mathrm{H}_{2} \mathrm{O}_{2}$ diluted in $100 \mathrm{mM}$ potassium phosphate buffer ( $\mathrm{pH}$ 7) was prepared. The reaction was initiated after adding $20 \mu \mathrm{L}$ of the $\mathrm{CEE}$, and the enzyme activity was measured by the rate of $\mathrm{H}_{2} \mathrm{O}_{2}$ decomposition at 240 nm using spectrophotometer for $3 \mathrm{~min}$ at $25^{\circ} \mathrm{C}$. (Cakmak and Horst, 1991). The APX activity was determined following the method of Cakmak and Marschner (1992). The reaction mixture (in a volume of $980 \mu \mathrm{L}$ ) composed of $100 \mathrm{mM}$ potassium phosphate buffer ( $\mathrm{pH} 6.8$ ), $2 \mathrm{mM} \mathrm{H}_{2} \mathrm{O}_{2}$, and $0.5 \mathrm{mM}$ ascorbate was added to $20 \mu \mathrm{L}$ of $\mathrm{CEE}$ to start the reaction. Ascorbate oxidation at $290 \mathrm{~nm}$ was measured to determine the APX activity. The POX activity was assayed following the colorimetric determination of pyrogallol oxidation according to Hasan et al. (2011). The reaction mixture (in a volume of $980 \mu \mathrm{L}$ ) contained $100 \mathrm{mM}$ potassium phosphate ( $\mathrm{pH} 6.8$ ), 20 $\mathrm{mM}$ pyrogallol, and $70 \mathrm{mM} \mathrm{H}_{2} \mathrm{O}_{2}$ was added to $20 \mu \mathrm{L}$ of CEE to start the reaction. Enzyme activity was measured following a record of absorbance of colored purpurogallin at $420 \mathrm{~nm}$ for $3 \mathrm{~min}$ at room temperature. The specific activity of the enzymes was expressed as $\mathrm{U} / \mathrm{mg} \mathrm{protein}$.

To measure MDA content, lyophilized tissue $(100 \mathrm{mg}$ ) was extracted with $0.1 \%$ trichloroacetic acid (TCA). After centrifuging at $8000 \times \mathrm{g}$ for $30 \mathrm{~min}, 250 \mu \mathrm{L}$ of supernatant was added to $1 \mathrm{~mL}$ of $0.5 \%$ thiobarbituric acid (TBA) prepared in $20 \%$ TCA solution. The mixture was incubated at $95{ }^{\circ} \mathrm{C}$ for 30 min, cooled in an ice bath, and then centrifuged at $10,000 \times \mathrm{g}$ for $15 \mathrm{~min}$. The absorbance of the supernatant was measured at $532 \mathrm{~nm}$ and non-specific absorbance was measured at $600 \mathrm{~nm}$. The MDA concentration was defined by its extinction coefficient of $155 \mathrm{mM}^{-1} \mathrm{~cm}^{-1}$ (Stewart and Bewley, 1980).

The $\mathrm{H}_{2} \mathrm{O}_{2}$ concentration was measured on lyophilized tissue crushed in $5 \mathrm{ml}$ of cold $0.1 \%(\mathrm{w} / \mathrm{v})$ TCA and then centrifuged for 15 min at $12000 \times \mathrm{g}$ in a refrigerated centrifuge. The supernatant $(0.5 \mathrm{~mL})$ was added to $100 \mathrm{mM}$ phosphate buffer $(\mathrm{pH} 7.0)$ and $1 \mathrm{M}$ of iodate potassium $(\mathrm{KI})$ solution and the absorbance was measured at $390 \mathrm{~nm}$ (Loreto and Velikova, 2001). The amount of $\mathrm{H}_{2} \mathrm{O}_{2}$ was calculated using a standard curve prepared with known concentrations of $\mathrm{H}_{2} \mathrm{O}_{2}$.

qRT-PCR analysis of the defense-related genes

Total RNA was isolated from fresh shoots using TRIzol ${ }^{\circledR}$ (Invitrogen). One microgram RNA was used for synthesizing cDNA after treating with RNase-free DNase I (BioLabs) using the RevertAid First Strand cDNA Synthesis kit (Thermo Fisher Scientific). Gene expression was assayed using Roche LightCycler ${ }^{\circledR} 96$ real-time PCR system and iQ SYBR Green Supermix kit (BioRad), according to the manual description.

Transcription of each gene was studied by RT-PCR with $0.5 \mu \mathrm{L}$ of $10 \mathrm{pM}$ of each forward and reverse specific primer designed in this study (Table 1 ) and $1 \mu \mathrm{L}$ of template cDNA (100 ng). The following PCR profile was used: $5 \mathrm{~min}$ at $95^{\circ} \mathrm{C} ; 40$ cycles $\left(30 \mathrm{~s}\right.$ at $95^{\circ} \mathrm{C}, 30 \mathrm{~s}$ at $64^{\circ} \mathrm{C}, 30 \mathrm{~s}$ at $\left.72^{\circ} \mathrm{C}\right) ; 10 \mathrm{~min}$ at $72{ }^{\circ} \mathrm{C}$ and recording melting curve. The transcription of the $\mathrm{EF}$ (elongation factor) gene was used as an internal control. Gene expression ratio was calculated using the REST 2009 software (Pfaffl et al., 2002).

Statistical analysis

Statistical analysis was performed using analysis of variance (ANOVA) by SPSS windows version 16.0 (SPSS Inc., Chicago, IL, USA). The significance of difference between treatments were analyzed using Duncan test at level of $P \leq 0.05$.

\section{Results}

Isolation of Actinomycetes

In this research, the total number of colonies were isolated from 12 fields was 6596 . The abundance of bacteria (cfu/g dry soil) isolated from different fields was not the same and differences in the number of colonies isolated from the rhizosphere and bulk soils of cucumber and tomato fields were significant $(P \leq$ 0.01). In contrast, there were no significant differences in richness of culturable bacteria between the rhizosphere and bulk soils of all three wheat fields. Also, there was not a significant difference between wheat fields. The differences between the number of colonies isolated from the rhizosphere and bulk soils of maize fields were not significant too (Fig. 1). Compared to dicots, the ratio of colonies isolated from bulk soils were higher in monocots fields. Also, the distribution of culturable bacteria in the rhizosphere and bulk soils of maize and wheat was similar to each other. This status was observed for dicots, cucumber and tomato too (Fig. 2). About twenty percent of the representative colonies (1335 of 6596) showed Actinomycetes appearance including compact colored heaped and chalky, waxy, wrinkled, powdery or velvety after culture on ISP2 medium and possessed an earthy odor or a good scent like vanilla. The share of tomato, cucumber, maize and wheat from total Actinomycetes isolates were $27 \%, 35 \%, 20 \%$ and $18 \%$ respectively (Fig. 3 ). In total, nine hundred and six (69\%) and 405 (31\%) Actinomycetes colonies were isolated from rhizosphere and bulk soils respectively. 
Antifungal activity

One hundred and six Actinomycetes isolates (8\%) that showed antagonistic activity against $P$. capsici were selected for further analysis. In some fields, the antagonistic Actinomycetes were found in both rhizosphere and bulk soils and in others, antagonistic isolates were observed only in rhizosphere or bulk soil. Furthermore, lots of the Actinomycetes isolates (64\%) were isolated from bulk soils (Fig. 4a). The share of monocots and dicots from total antagonistic isolates were $79 \%$ and $21 \%$ respectively (Fig. $4 \mathrm{~b}$ ). All of the antagonistic isolates (isolated based on the inhibition of $P$. capsici growth) showed antagonistic activity against $P$. drechsleri, P. ultimum (31\%), R. solani (45\%) and F. oxysporum (45\%). The number of antagonistic isolates, which is isolated from monocot crops was higher than dicots, among them, wheat possess higher antagonistic isolates (Table 2). Twenty out of 106 antagonistic isolates showed an inhibitory effect against all the five phytopathogenic fungi.

Hydrolytic enzymes activity

All 16 (100\%) antagonistic Actinomycetes that were isolated from the dicots fields had cellulase activity (Table 2), while this ratio was only $70 \%$ for monocots. Thirty out of 106 (28\%) antagonistic isolates had chitinase activity which of these, $23 \%$ and $77 \%$ belonged to dicots and monocots fields respectively. At a different glance, $44 \%$ and $26 \%$ of antagonistic Actinomycetes that were isolated from the dicots and monocots fields respectively had chitinase activity. The shares of rhizosphere and bulk soils from isolates with the ability to inhibit $P$. capsici were $39 \%$ and $61 \%$ respectively, which were in accordance with their share in cellulase activity (Table 2).

PGP activity

Seventeen, 26 and 42 antagonistic isolates had the ability to grow on $\mathrm{N}$ free medium, solubilize inorganic phosphate and produce siderophore respectively. All 106 isolates were able to produce IAA (Table 2). Only three Actinomycetes, one of them isolated from cucumber bulk soil (isolate 3415) and the others from maize rhizosphere soil (strains 1119 and 1331), had all tested PGP traits (Table 3). Compared to bulk soils, most of PGP Actinomycete were resident in the rhizosphere. The numbers of the isolates had one of the PGP traits, were more in the monocots fields but the percentages of antagonistic isolates had PGP activity were higher in the dicots fields (Table 2). Thirteen isolates with both antagonistic and PGP traits were selected for further studies (Table 3).

Genotypic characterization of superior isolates and Phylogenetic tree of strain 1119

It is apparent from table 3 that Actinomycetes, which were isolated from dicots and monocot soils, were associated with two genus Streptomyces and Amycolatopsis. The diversity of genus and species of Actinomycete were higher in dicots in comparison with monocots. While all isolates from wheat fields belong to S. monomycini and most of the strains of maize soils belong to different species of Amycolatopsis (some of the results are shown in Table 3 ). The initial analysis of the $16 \mathrm{~s}$ rRNA gene sequence showed that strain 1119 is associated with species of the genus Amycolatopsis with $99.22 \%$ and $99.15 \%$ sequence similarity to $A$. thailandensis JCM $16380^{\top}$ (NMQT01000085) and $A$. umgeniensis UM $16^{\top}$ (DQ110876) respectively. Also, the constructed phylogenetic tree from 16s rRNA illustrates that isolate 1119 is a member of the Amycolatopsis genus and is placed in a clade with these two type strains (Fig. 5)

Greenhouse experiments

Experiment 1: Evaluation of superior species for cucumber growth-promoting activity

There were significant differences between seed germination in the untreated control group and Actinomycete treatments (Table 4). Compared to the control group, seed germination in treatment with strain $1118,1331,3415,407$ and 405 was $35 \%, 60 \%, 80 \%, 80 \%$ and $100 \%$ lower, respectively. Also, the growth of germinated seeds in the soil treated with these bacteria was less. Strains 3637 and 1317, which did not have a negative effect on seed germination, also reduced seedling growth. On the contrary, as is shown in fig. 7, the plants which grown in soil treated with strains 3513, 1119, 432 or 615 , increased shoot length and fresh and dry shoot weight compared to the control. Increase in fresh and dry weight of shoot was in the range of $11-43 \%$ and $9-25 \%$ respectively (Table 4).

Experiment 2: Biocontrol activity of superior PGP strains

Four strains $615,1119,3513$ and 432 that caused a significant increase in root dry and fresh weight (Fig. 6) were selected to biocontrol activity evaluation. Thirteen days after seedlings inoculation with $P$. capsici, the damping-off symptom was observed. The highest incidence of the disease was in the untreated control and was about $80 \%$. Strains $432,3513,615$ and 1119 controlled incidence of the disease by $65 \%, 42 \%, 83 \%$ and $100 \%$ respectively (Fig. 7 ). The PGP activity of strains 3513 and 1119 was observed for the second time in this experiment as an increase in shoot and root fresh and dry weight (Fig. 8).

Experiment 3: Performance evaluation of strain 1119 at the commercial greenhouse conditions

In the control group, fruit yield was $3.9 \mathrm{ton} / 1000 \mathrm{~m}^{2}$ in a period of one month. Application of strain 1119 significantly increased fruit yield by $20 \%$ (4.7 ton $/ 1000 \mathrm{~m}^{2}$ ) compared to untreated control (Table 5). Sensory evaluation showed that cucumber fruit did not differ significantly from control in the bacterial treatment. However, the fruit score in the bacterial group in terms of juiciness and sweetness was $4 \%$ higher and $3 \%$ lower than the control, respectively. These results were consistent with the results of the total soluble sugar content and percentage of dry weight of the fruit. As is shown in table 5 , soil treatment with strain 1119 significantly reduced fruit dry weight percentage (31\%) and total soluble sugar content (14\%) compared to control. Decreased fruit nitrate content was another effect of bacteria on fruit quality. The content of cucumber nitrate in the bacterial treatment was $9.58 \mathrm{mg} / 100 \mathrm{~g}$ fresh fruit weight less than onethird of the amount of nitrate in the control group (Table 5). 
Bacterial treatment increased the level of antioxidant enzymes without significantly altering the amount of leaf protein. The highest increases were in CAT (150\%), followed by APX (54\%) and POX (25\%). Increased activity of these enzymes was associated with a reduction in $\mathrm{H}_{2} \mathrm{O}_{2}$ level by $50 \%$ compared with control. Following the reduction of destructive agent $\mathrm{H}_{2} \mathrm{O}_{2}$ in the bacterial treatment, the level of MDA, which indicates cell destruction, was $37 \%$ lower than the control (Table 6). Here, the results of gene expression study using RT-PCR showed that the relative frequency of LOX transcription in bacterial treatment was significantly higher than the control. The relative increase in APX transcription and the subsequent increase in APX activity also showed that strain 1119 stimulated plant-induced resistance at the transcription level without pathogen exposure. Systemic acquired resistance (SAR) is associated with the expression of SAR genes that lead to the accumulation of defense proteins. PR1-1a and GLU are two SAR genes that were induced by strain 1119 (Fig. 9).

\section{Discussion}

There are many studies have showed rhizosphere effect on bacterial communities. These reports state that rhizosphere effect is different between plant species due to plant growth stage and root physiology, structure and exudation (Liu et al., 2019; Sasse et al., 2018; Samad et al., 2017; Edwards et al., 2015). Turner et al. (2013) studied the soil microbiome and revealed a higher rhizosphere effect in pea (dicot) compared to oat and wheat (monocots). As we expected, the number of culturable bacteria in the rhizosphere of monocot crops was not higher than in the bulk soil. Although the cause is not exactly known, three points can be made. First, the roots of wheat and maize do not secrete substances that are attractive or usable to bacteria. Various traits give a bacterium the ability to colonize rhizosphere. Although, most studies on the issue have focused on fluorescent Pseudomonas spp., one of the most abundant bacteria in the rhizosphere, and cannot be generalized to all cultivable bacteria. It is illustrated that cheA1 gene is essential for chemotaxis towards root exudates in Pseudomonas fluorescens strains and cheA1 mutants are not able to colonize the roots of alfalfa (Muriel et al., 2015). de Weert et al., (2002) experiments showed that some organic acids and almost all amino acids have found in tomato root exudate are chemo-attractants for $P$. fluorescens. However, this chemotactic response was not detected toward sugars in the exudate. Studies on root exudates of dicots plants including tomato, cucumber, and sweet pepper have shown that the total amount of organic acid was much higher than that of total sugars (Kamilova et al., 2006) while in grasses (monocot plants) these two groups of compounds have an equal share (Kuiper et al. 2002). Second, wheat and barley roots produce metabolites that induce the antagonistic activities of some bacteria are resident in the rhizosphere. P. fluorescens strains produce the secondary metabolite 2,4-diacetylphloroglucinol (2,4-DAPG), with antibiotic properties. Notz et al., (2001) showed that expression of phlA (a gene is involved in DAPG biosynthesis) was increased four- fold in the rhizosphere of maize and wheat (two monocots) compared to the rhizosphere of bean and cucumber (two dicots). Third, studied monocots may have attracted endophytic bacteria and have them inside the root tissues. According to studies by Mercado-Blanco et al. (2016) P. fluorescens PICF7 selectively develops an endophytic lifestyle in two monocots (wheat and barley) roots but not in a dicots plant (Arabidopsis thaliana). The presence of Actinomycetes in the rhizosphere of both monocot and dicot plants has been reported (reviewed in Kumar and Dubey, 2020). The ability of Actinomycete strains to colonize rhizosphere of both monocots and dicots plants has also been demonstrated (Gopalakrishnan et al., 2013). Based on our results, the chance of finding an Actinomycete in the cucumber rhizosphere is higher than in other areas we have studied. Although, to the best of our knowledge, no study has been conducted on comparing the abundance of Actinomycetes in the soil of monocots and dicots fields.

Potential antagonistic Actinomycete strains have been isolated from rhizosphere soil of vegetable crops, especially cucumber and tomato (Chaurasia et al., 2018). However, it is not clear whether the Actinomycete strains isolated from the rhizosphere of cucumber and tomato are $P$. capsici antagonist. Because $P$. capsici often causes disease in pepper, most of the Actinomycetes that inhibit the growth of this pathogen have been isolated from the rhizosphere of kinds of pepper (Joo, 2005; Balaraju et al., 2016).

Cellulose is one of the most important components of the cell wall of the phytopathogen Phytophthora and is sensitive to the enzyme cellulase. The production of cellulase by antagonistic bacteria in the vicinity of plant roots is one of the ways to prevent the spread of phytopathogenic fungi and disease. Loliam et al. (2012) and Sadeghi et al., (2017) reported antagonistic activity of cellulase-producing Actinomycetes against Phytophthora. The correlation between the two traits of cellulose production and inhibition of Phytophthora growth shows that searching among cellulase-producing bacteria shortens the path of selection of Phytophthora antagonist bacteria. Interestingly, such an association is not observed between chitinase production and inhibition of the growth of fungi such as Rhizoctonia and Fusarium that have chitin in their cell walls.

Abbasi et al., (2019) reported that growth ability on a nitrogen-free medium and production of auxin are common traits of Streptomyces isolates isolated from the rhizosphere of tomato and cucumber, and only $30 \%$ of the isolates have potential to solubilize inorganic phosphate. Although bacteria that stimulate plant growth often have several PGP traits, it is possible that bacteria with these traits may not necessarily stimulate plant growth or have different effects on different plants. For example, Streptomyces rimosus strain C-2012, which has PGP traits auxin and siderophore production and inorganic phosphate solubilization (Sadeghi et al., 2012), increased the growth of cucumber (Sadeghi et al., 2017) and peppermint (Esmaeil Zade et al., 2019), although its positive effect on wheat was cultivar-dependent (Akbari et al., 2020). Unfortunately, despite the many studies that have been done, there is still no trait that its presence in Actinomycetes assures us of its positive effect on the growth and yield of all plants.

Amycolatopsis are isolated from the rhizosphere of various plants such as rice (Thawai et al., 2018), canola (Lay et al., 2018), birch (Ostash et al., 2014), Panax notoginseng (Peng et al., 2019), eucalyptus (Himaman et al., 2016).

Strain 1119 , which belongs to the genus Amycolatopsis, raised fresh and dry shoot weight up to $25 \%$ and $17 \%$ respectively. Strain 3415 which antagonize three plant pathogens $P$. capsici, $P$. drechsleri and $P$. ultimum and was positive for all four studied PGP traits suppressed seed germination and plant growth. In contrast, strain 1119, which was similar to strain 3415 in terms of studied traits, increased plant growth. Strain 1119 and 3415 have most similarity to $A$. thailandensis (99.22\%) and A. roodepoortensis (98.65\%) respectively. More interestingly, strains 614 and 615 , both of which are very similar ( $\mathbb{9} 99.65 \%)$ to $S$. monomycini and are quite similar in terms of PGP traits and phytopathogens antagonism, had different effects on the cucumber growth. The same is true for two strains of $A$. roodepoortensis, 3415 and 3513 . The effect of strains 407, 405 and 1331, all three of which are most similar to $A$. lurida, on germination and growth of cucumber was negative. Based on these results, the observed negative effect is related to this species and is not related to the ability to dissolve 
inorganic phosphate (strain 1331) or lack of this ability (407 and 405). Despite all of these, the positive effect of strain 1119 on cucumber growth, which is positive for ability to grow on $\mathrm{N}$ free medium, siderophore production and inorganic phosphate solubilization, compared to the lack of effect of strain 432 , which is negative for these traits, tempt us to use PGP traits for screening and selecting effective PGPRs in subsequent applications too. However, a closer look at the molecular mechanisms involved in the plant-bacteria interaction to find selectable markers more effective than PGP traits is necessary. Alekhya and Gopalakrishnan (2016) have shown for the first time that one strain of Amycolatopsis sp. BCA-696, isolated from rhizosphere soil of chickpea, is able to promote chickpea and sorghum growth. PGP activity of this strain is related to the production of IAA and siderophore and its good hydrolytic enzyme activity. Amycolatopsis sp. strain CRJ2-11 with high similarity (99\%) to A. keratiniphila was able to produce IAA and siderophore as well as to solubilize inorganic phosphate (Ningthoujam et al., 2016). In contrast, there are strains of this bacterium such as $A$. pretoriensis strain SA3 that do not have any of the PGP traits (Borah and Thakur, 2020). Apart from study on chickpeas and sorghum (Alekhya and Gopalakrishnan, 2016), the effect of Amycolatopsis species on plants is still unknown. To our knowledge, this is the first report of PGP traits of strains similar to $A$. thailandensis and $A$. roodepoortensis and their positive effects on cucumber growth.

Strain 1119, which completely controlled the disease of seedling damping-off and increased shoot and root dry weight in two separate experiments 1 and 2 , was selected for evaluation in commercial greenhouse conditions. Because Actinomycetes have always been considered as sources of antibiotic production (Genilloud, 2017), most reports of these bacteria are about their antagonistic and biocontrol properties. The effect of Actinomycetes on increasing growth and controlling cucumber Pythium (El-Tarabily et al., 2009), Fusarium (Li et al., 2014) and Phytophthora (Sadeghi et al., 2017) diseases has been previously reported. The bacteria reported in most similar studies belong to the largest genus of Actinomycete, Streptomyces. The valuable potential of the rare Actinomycetes to increase crops yield and control their diseases is not well known. There are few but promising reports about these rare bacteria. Successful biocontrol of sorghum charcoal rot disease caused by Macrophomina phaseolina has been reported by a PGP strain of Amycolatopsis (Gopalakrishnan et al., 2019). Complete control of cucumber seedling fluctuations by 1119 pressure observed in this study could be another promising report.

Application of strain 1119 under commercial greenhouse conditions resulted in an increase in fruit yield (20\%) and juice and a decrease in fruit nitrate content (70\%). Nitrate in the human digestive system reduces to nitrite, a harmful product. Therefore, there are restrictions on the consumption of foods containing nitrate (Santamaria, 2006). Cucumber juice is rich in a variety of vitamins, fiber, minerals and antioxidants beneficial to health and slimming diets (Henning et al., 2017). Bacterial treatment by reducing the nitrate content can reduce the limitations of its use.

There are many articles on the positive effect of antagonistic PGP bacteria on plant growth and yield and control of their diseases in conditions of research greenhouse. The results of these studies pave the way to produce commercially available formulations. Although the number of articles describing the effect of selected bacteria in commercial greenhouse and farm conditions is much smaller, fortunately, the products on the market show that the impact of them is positive and acceptable. Actinovate and Mycostop are two Actinomycete based formulation commercially available as bio fungicide that introduced to control soil-borne fungal diseases caused by Fusarium, Rhizoctonia, Pythium, Phytophthora (Vurukonda et al., 2018; www.novozymes.com). However, there are articles on other crops, we did not find a report that shows the positive effect of these products on cucumber yield and quality and control of fungal diseases under commercial field conditions. On the other hand, El-Tarabily et al. (2010) reported an increase in cucumber yield and a decrease in Pythium disease (seedling damping-off, and root and crown rots) after the use of $S$. spiralis in commercial farm conditions. Such studies together with the present study demonstrated the effectiveness of biocontrol agents for use in cucumber commercial greenhouses. Though it is not possible to artificially infect plant with pathogens in a commercial greenhouse, there are good markers such as known enzymes and genes involved in stimulating the plant defense system that indicate the plant is ready to deal with possible pathogens. Bacterial treatment increased the level of antioxidant enzymes without significantly altering the amount of leaf protein.

The ability of growth-promoting Trichoderma longibrachiatum T6 to increase wheat growth under normal and saline conditions was associated with increased the activity of antioxidant enzymes and decreased the content of $\mathrm{H}_{2} \mathrm{O}_{2}$ and MDA (Zhang et al., 2019). Induced systemic resistance (ISR) and systemic acquired resistance (SAR) are two forms of plant-defense induction resistance that reduce disease damages if started before the plant is exposed to pathogens (Choudhary et al., 2007). It is reported that the induction of ISR by PGPRs is associated with an increase in LOX activity (Akram et al., 2008). Increased antioxidant enzymes activity and increased $L O X$ and $A P X$ transcription showed that strain 1119 induced plant ISR without pathogen exposure. SAR is associated with the expression of SAR genes that lead to the accumulation of defense proteins (Conrath, 2006). PR1-1a and GLU are two SAR genes that were induced by strain 1119. Our result suggests that this PGP bacterium could induce both ISR and SAR in cucumber. Stimulation of both types of systemic resistance by Streptomyces in tomato has been reported by Abbasi et al. (2019).

\section{Conclusion}

According to the results of this study, the culturable Actinomycetes population in the rhizosphere of dicots is higher than monocots. However, the number of antagonist Actinomycetes in the rhizosphere of dicots is less and more antagonist Actinomycete bacteria were obtained from bulk soil of monocots fields. These results are important because the studied pathogens are related to dicotyledonous plants. Therefore, when our resources are limited, it may be best to screen the bulk soil of monocot plants first. Although the diversity of Actinomycetes in these regions was less than that of the rhizosphere of dicots, the antagonistic activity of the strains was higher. Another noteworthy point that can be mentioned is the lack of a direct relationship between the plant growthpromoting effect of an antagonistic strain and its PGP traits. Therefore, instead of studying these traits in the screening phase, it may be better to do so in the mechanism finding phase after observing the positive effect of bacteria on plant growth. Here, for the first time, we show the different effects of four species of Amycolatopsis on cucumber. These results suggest that there are still many beneficial bacteria in the soil that have not been identified. Overall, these results support the theory that the artificial introduction of BSRs into the soil can stimulate the plant immune system, control disease, and increase its growth.

\section{Declarations}


The authors are grateful to the Agricultural Biotechnology Research Institute of Iran (ABRII), for financial support of this project [grant number: 14-05-05-01109454-970581]

\section{Conflict of interest}

Authors declare that there exists no conflict of interest among them

\section{References}

1. Abbasi S, Safaie N, Sadeghi A, Shamsbakhsh M (2019) Streptomyces Strains Induce Resistance to Fusarium oxysporum sp. lycopersici Race 3 in Tomato Through Different Molecular Mechanisms. Front Microbiol 10:1505

2. Abbasi, S., Safaie, N., Sadeghi, A., Shamsbakhsh, M. 2020. Tissue-specific synergistic bio-priming of pepper by two Streptomyces species against Phytophthora capsici. PLoS ONE, 15(3): e0230531

3. Akbari A, Gharanjik S, Koobaz P, Sadeghi A (2020) Plant growth promoting Streptomyces strains are selectively interacting with the wheat cultivars especially in saline conditions. Heliyon 6:e03445

4. Alekhya G, Gopalakrishnan S (2016) Exploiting plant growth-promoting Amycolatopsis in chickpea and sorghum for improving growth and yield. Legume Res 29:225-231

5. Alexander D, Zuberer D (1991) Use of chrome azurol S reagents to evaluate siderophore production by rhizosphere bacteria. Biol Fertil 12:39-45

6. Bakker MG, Glover JD, Mai JG, Kinkel LL (2010) Plant community effects on the diversity and pathogen suppressive activity of soil streptomycetes. Appl Soil Ecol 46:35-42

7. Bakker MG, Otto-Hanson L, Lange A, Bradeen JM, Kinkel LL (2013) Plant monocultures produce more antagonistic soil Streptomyces communities than high-diversity plant communities. Soil Biol 65:304-312

8. Balaraju K, Kim C-J, Park D-J, Nam K-W, Zhang K, Sang MK, Park K (2016) Paromomycin derived from Streptomyces AG-P 1441 induces resistance against two major pathogens of chili pepper. Microb Biotechnol 26:1542-1550

9. Berger LR, Reynold DM (1958) The chitinase system of a strain of Streptomyces griseus. BBA-Geb Subjects 29:522-534

10. Borah A, Thakur D (2020) Phylogenetic and Functional Characterization of Culturable Endophytic Actinobacteria Associated With Camellia for Growth Promotion in Commercial Tea Cultivars. Front Microbiol 11:318

11. Brzezinska MS, Jankiewicz U, Burkowska A, Walczak M (2014) Chitinolytic microorganisms and their possible application in environmental protection. Curr Microbiol 68:71-81

12. Café-Filho AC, Ristaino JB (2008) Fitness of isolates of Phytophthora capsici resistant to mefenoxam from squash and pepper fields in North Carolina. Plant Dis 92:1439-1443

13. Chaurasia A, Meena B, Tripathi A, Pandey K, Rai A, Singh B (2018) Actinomycetes: an unexplored microorganisms for plant growth promotion and biocontrol in vegetable crops. World J Microbi Biot 34:132

14. Choudhary DK, Prakash A, Johri B (2007) Induced systemic resistance (ISR) in plants: mechanism of action. Indian J Microbiol 47:289-297

15. Chun J, Goodfellow M (1995) A phylogenetic analysis of the genus Nocardia with 16S rRNA gene sequences. Int J Syst Bacteriol 45:240-245 doi:10.1099/00207713-45-2-240

16. Conrath U (2006) Systemic acquired resistance. Plant Signal Behav 1:179-184

17. Cordovez V, Carrion VJ, Etalo DW, Mumm R, Zhu H, Van Wezel GP, Raaijmakers JM (2015) Diversity and functions of volatile organic compounds produced by Streptomyces from a disease-suppressive soil. Front Microbiol 6:1081

18. Dahal B, NandaKafle G, Perkins L, Brözel VS (2017) Diversity of free-Living nitrogen fixing Streptomyces in soils of the badlands of South Dakota. Microbiol Res 195:31-39

19. Davelos AL, Xiao K, Samac DA, Martin AP, Kinkel LL (2004) Spatial variation in Streptomyces genetic composition and diversity in a prairie soil. Microb Ecol 48:601-612

20. de Weert S et al. (2002) Flagella-driven chemotaxis towards exudate components is an important trait for tomato root colonization by Pseudomonas fluorescens. Mol Plant Microbe Interact 15:1173-1180

21. Dubois M, Gilles KA, Hamilton JK, Rebers Pt, Smith F (1956) Colorimetric method for determination of sugars and related substances. Anal Chem 28:350356

22. Edwards $\mathrm{J}$ et al. (2015) Structure, variation, and assembly of the root-associated microbiomes of rice. PNAS 112:E911-E920

23. El-Tarabily KA, Hardy GESJ, Sivasithamparam K (2010) Performance of three endophytic actinomycetes in relation to plant growth promotion and biological control of Pythium aphanidermatum, a pathogen of cucumber under commercial field production conditions in the United Arab Emirates. Eur $\mathrm{J}$ Plant Pathol 128:527-539

24. El-Tarabily KA, Sivasithamparam K (2006) Non-streptomycete actinomycetes as biocontrol agents of soil-borne fungal plant pathogens and as plant growth promoters. Soil Biol Biochem 38:1505-1520

25. El-Tarabily K, Nassar A, Hardy GSJ, Sivasithamparam K (2009) Plant growth promotion and biological control of Pythium aphanidermatum, a pathogen of cucumber, by endophytic actinomycetes. Appl Microbiol 106:13-26

Page 9/19 
26. Esmaeil Zade NSE, Sadeghi A, Moradi P (2019) Streptomyces strains alleviate water stress and increase peppermint (Mentha piperita) yield and essential oils. Plant Soil 434:441-452

27. Genilloud O (2017) Actinomycetes: still a source of novel antibiotics. Nat Prod Rep 34:1203-1232

28. Gopalakrishnan S, Srinivas V, Naresh N, Alekhya G, Sharma R (2019) Exploiting plant growth-promoting Amycolatopsis for bio-control of charcoal rot of sorghum (Sorghum bicolor L.) caused by Macrophomina phaseolina (Tassi) Goid. Arch Phytopathol Pflanzenschutz 52:543-559

29. Gopalakrishnan S, Srinivas V, Vidya MS, Rathore AJS (2013) Plant growth-promoting activities of Streptomyces in sorghum and rice. SpringerPlus 2:574

30. Henning SM et al. (2017) Health benefit of vegetable/fruit juice-based diet: Role of microbiome. Sci Rep 7:1-9

31. Himaman W, Thamchaipenet A, Pathom-aree W, Duangmal K (2016) Actinomycetes from Eucalyptus and their biological activities for controlling Eucalyptus leaf and shoot blight. Microbiol Res 188:42-52

32. Hsu S, Lockwood J (1975) Powdered chitin agar as a selective medium for enumeration of actinomycetes in water and soil. Appl Environ Microbiol 29:422-426

33. Islam S, Akanda AM, Prova A, Islam MT, Hossain MM (2016) Isolation and identification of plant growth promoting rhizobacteria from cucumber rhizosphere and their effect on plant growth promotion and disease suppression. Front Microbiol 6:1360

34. Joo G-J (2005) Production of an anti-fungal substance for biological control of Phytophthora capsici causing phytophthora blight in red-peppers by Streptomyces halstedii. Biotechnol Lett 27:201-205

35. Kamilova F, Kravchenko LV, Shaposhnikov Al, Azarova T, Makarova N, Lugtenberg B (2006) Organic acids, sugars, and L-tryptophane in exudates of vegetables growing on stonewool and their effects on activities of rhizosphere bacteria. Mol Plant Microbe Interact 19:250-256

36. Karimi E, Sadeghi A, Abbaszadeh Dahaji P, Dalvand Y, Omidvari M, Kakuei Nezhad M (2012) Biocontrol activity of salt tolerant Streptomyces isolates against phytopathogens causing root rot of sugar beet. Biocontrol Sci Techn 22:333-349 doi:10.1080/09583157.2012.658552

37. Kinkel LL, Bakker MG, Schlatter DC (2011) A coevolutionary framework for managing disease-suppressive soils. Annu Rev Phytopathol 49:47-67

38. Kuiper I, Kravchenko LV, Bloemberg GV, Lugtenberg BJ (2002) Pseudomonas putida strain PCL1444, selected for efficient root colonization and naphthalene degradation, effectively utilizes root exudate components. Mol Plant Microbe Interact 15:734-741

39. Kumar A, Dubey A (2020) Rhizosphere microbiome: Engineering bacterial competitiveness for enhancing crop production. J Adv Res

40. Landwehr W, Wolf C, Wink J (2016) Actinobacteria and myxobacteria-two of the most important bacterial resources for novel antibiotics. In: How to Overcome the Antibiotic Crisis. Springer, pp 273-302

41. Lareen A, Burton F, Schäfer P (2016) Plant root-microbe communication in shaping root microbiomes. Plant Mol Biol 90:575-587

42. Lay C-YB, Terrence H, Hamel C, Harker KN, Mohr R, Greer CW, Yergeau É, St-Arnaud M (2018) Canola root-associated microbiomes in the Canadian Prairies. Front Microbiol 9:1188

43. Li X et al. (2014) Staurosporine from the endophytic Streptomyces strain CNS-42 acts as a potential biocontrol agent and growth elicitor in cucumber. Anton Leeun Int J G 106:515-525

44. Liu F, Hewezi T, Lebeis SL, Pantalone V, Grewal PS, Staton ME (2019) Soil indigenous microbiome and plant genotypes cooperatively modify soybean rhizosphere microbiome assembly. BMC microbiology 19:1-19

45. Mercado-Blanco J, Alós E, Rey MD, Prieto P (2016) Pseudomonas fluorescens PICF7 displays an endophytic lifestyle in cultivated cereals and enhances yield in barley. FEMS Microbiol Ecol 92:fiw092

46. Mingma R, Pathom-aree W, Trakulnaleamsai S, Thamchaipenet A, Duangmal K (2014) Isolation of rhizospheric and roots endophytic actinomycetes from Leguminosae plant and their activities to inhibit soybean pathogen, Xanthomonas campestris glycine. World J Microbiol Biotechnol 30:271-280 doi:10.1007/s11274-013-1451-9

47. Muriel C, Jalvo B, Redondo-Nieto M, Rivilla R, Martín M (2015) Chemotactic motility of Pseudomonas fluorescens F113 under aerobic and denitrification conditions. PloS one 10:e0132242

48. Ningthoujam D, Lynda R, Tamreihao K, Chanu S, Aruna K, Jeenita N (2016) Isolation and characterization of Amycolatopsis strain CRJ2-11 with biocontrol and plant growth-promoting potential from upland rice rhizosphere in Manipur, India. Elyns J Microbes 1:104

49. Niu J, Rang Z, Zhang C, Chen W, Tian F, Yin H, Dai L (2016) The succession pattern of soil microbial communities and its relationship with tobacco bacterial wilt. BMC microbiology 16:233

50. Notz R, Maurhofer M, Schnider-Keel U, Duffy B, Haas D, Défago G (2001) Biotic factors affecting expression of the 2, 4-diacetylphloroglucinol biosynthesis gene phIA in Pseudomonas fluorescens biocontrol strain CHAO in the rhizosphere. Phytopathology 91:873-881

51. Ostash B, Gren T, Hrubskyy Y, Tistechok S, Beshley S, Baranov V, Fedorenko V (2014) Cultivable actinomycetes from rhizosphere of birch (Betula pendula) growing on a coal mine dump in Silets, Ukraine. J Basic Microbiol 54:851-857

52. Patten CL, Glick BR (2002) Role of Pseudomonas putida indoleacetic acid in development of the host plant root system. Appl Environ Microbiol 68:37953801 doi:10.1128/aem.68.8.3795-3801.2002

53. Peng G et al. (2019) Amycolatopsis panacis nov., isolated from Panax notoginseng rhizospheric soil. Int J Syst Evol Micr 69:567-571

54. Rangarajan S, Saleena LM, Vasudevan P, Nair S (2003) Biological suppression of rice diseases by Pseudomonas under saline soil conditions. Plant Dis 251:73-82

55. Sadeghi A, Karimi E, Dahaji PA, Javid MG, Dalvand Y, Askari H (2012) Plant growth promoting activity of an auxin and siderophore producing isolate of Streptomyces under saline soil conditions. World J Microb Biot 28:1503-1509 
56. Sadeghi A, Koobaz P, Azimi H, Karimi E, Akbari AR (2017) Plant growth promotion and suppression of Phytophthora drechsleri damping-off in cucumber by cellulase-producing Streptomyces. BioControl 62:805-819

57. Samad A, Trognitz F, Compant S, Antonielli L, Sessitsch A (2017) Shared and host-specific microbiome diversity and functioning of grapevine and accompanying weed plants. Environ Microbiol 19:1407-1424

58. Samira M, Mohammad R, Gholamreza G (2011) Carboxymethyl-cellulase and filter-paperase activity of new strains isolated from Persian Gulf. Microbiology 1:8-16

59. Santamaria $P(2006)$ Nitrate in vegetables: toxicity, content, intake and EC regulation. J Sci 86:10-17

60. Sasse J, Martinoia E, Northen T (2018) Feed your friends: do plant exudates shape the root microbiome? Trends Plant Sci 23:25-41

61. Schlatter D, Kinkel L, Thomashow L, Weller D, Paulitz T (2017) Disease suppressive soils: new insights from the soil microbiome. Phytopathology 107:1284-1297

62. Sharma V, Salwan R. (2018) Biocontrol potential and applications of Actinobacteria. Elsevier book volume on Actinobacteria: Diversity and Biotechnological applications 93-108

63. Soltani A-A, Khavazi K, Asadi-Rahmani H, Omidvari M, Dahaji PA, Mirhoseyni H (2010) Plant growth promoting characteristics in some Flavobacterium isolated from soils of Iran. Int J Sust Evol Micr 2:106

64. Tang S-K, Wang Y, Guan T-W, Lee J-C, Kim C-J, Li W-J (2010) Amycolatopsis halophila sp. nov., a halophilic actinomycete isolated from a salt lake. Int J Syst Evol 60:1073-1078

65. Tanvir R, Sajid I, Hasnain S (2014) Biotechnological potential of endophytic actinomycetes associated with Asteraceae plants: isolation, biodiversity and bioactivities. Biotechnol Lett 36:767-773 doi:10.1007/s10529-013-1430-0

66. Thawai C (2018) Amycolatopsis rhizosphaerae nov., isolated from rice rhizosphere soil. Int J Syst Evol Micr 68:1546-1551

67. Tripathi G, Rawal SK (1998) Simple and efficient protocol for isolation of high molecular weight DNA from Streptomyces aureofaciens. Biotechnol Tech 12:629-631 doi:10.1023/A:1008836214495

68. Turner TR et al. (2013) Comparative metatranscriptomics reveals kingdom level changes in the rhizosphere microbiome of plants. The ISME j 7:22482258

69. Vessey JK (2003) Plant growth promoting rhizobacteria as biofertilizers. Plant Soil 255:571-586

70. Viaene T, Langendries S, Beirinckx S, Maes M, Goormachtig S (2016) Streptomyces as a plant's best friend? FEMS Microbiol Ecol 92

71. Vurukonda SSKP, Giovanardi D, Stefani EJljoms (2018) Plant growth promoting and biocontrol activity of Streptomyces as endophytes. Int J Mol Sci 19:952

72. Weller DM, Raaijmakers JM, Gardener BB, Thomashow LS (2002) Microbial populations responsible for specific soil suppressiveness to plant pathogens. Annu Rev Phytopathol 40:309-348 doi:10.1146/annurev.phyto.40.030402.110010

73. Yuan WM, Crawford DL (1995) Characterization of streptomyces lydicus WYEC108 as a potential biocontrol agent against fungal root and seed rots. Appl Environ Microbiol 61:3119-3128

74. Zaller JG, Köpke U (2004) Effects of traditional and biodynamic farmyard manure amendment on yields, soil chemical, biochemical and biological properties in a long-term field experiment. Biol Fert Soils 40:222-229

75. Zhang S, Xu B, Gan Y (2019) Seed treatment with Trichoderma longibrachiatum T6 promotes wheat seedling growth under NaCl stress through activating the enzymatic and nonenzymatic antioxidant defense systems. Int J Mol Sci 20:3729

\section{Tables}

Table 1. Name of the target genes and sequences of primers designed and used in this study

\begin{tabular}{|c|c|}
\hline gene name & Sequence \\
\hline \multirow[t]{2}{*}{ elongation factor $(E F)$} & F-5'ACTGTGCTGTCCTCATTATTG3' \\
\hline & R-5'AGGGTGAAAGCAAGAAGAGC3' \\
\hline \multirow[t]{2}{*}{ pathogenesis-related protein 1-alpha (PR1-1a) } & F-5'TGCTCAACAATATGCGAACC3' \\
\hline & R-5'TCATCCACCCACAACTGAAC3' \\
\hline \multirow[t]{2}{*}{$\beta$-1,3-glucanases (GLU) } & F-5'CCGCTTCCTTCTCGACAACA3' \\
\hline & R-5'CCACСАTTСTTСTCСААAGCTG3 \\
\hline \multirow[t]{2}{*}{ linoleate 9S-lipoxygenase ( $L O X)$} & F-5'AAGGTTTGCCTGTCCCAAGAT3' \\
\hline & R-5'CTCCAGCCAACATTTCTCTTGC3 \\
\hline \multirow[t]{2}{*}{ ascorbate peroxidase $(A P X)$} & F-5'CCCGAAGTTCCTTTCCACCC3' \\
\hline & R-5'CCAATGTGTGACCACCAGAGA3' \\
\hline
\end{tabular}


Table 2. Number, isolation site and characteristics of 106 Actinobacteria isolated in this study

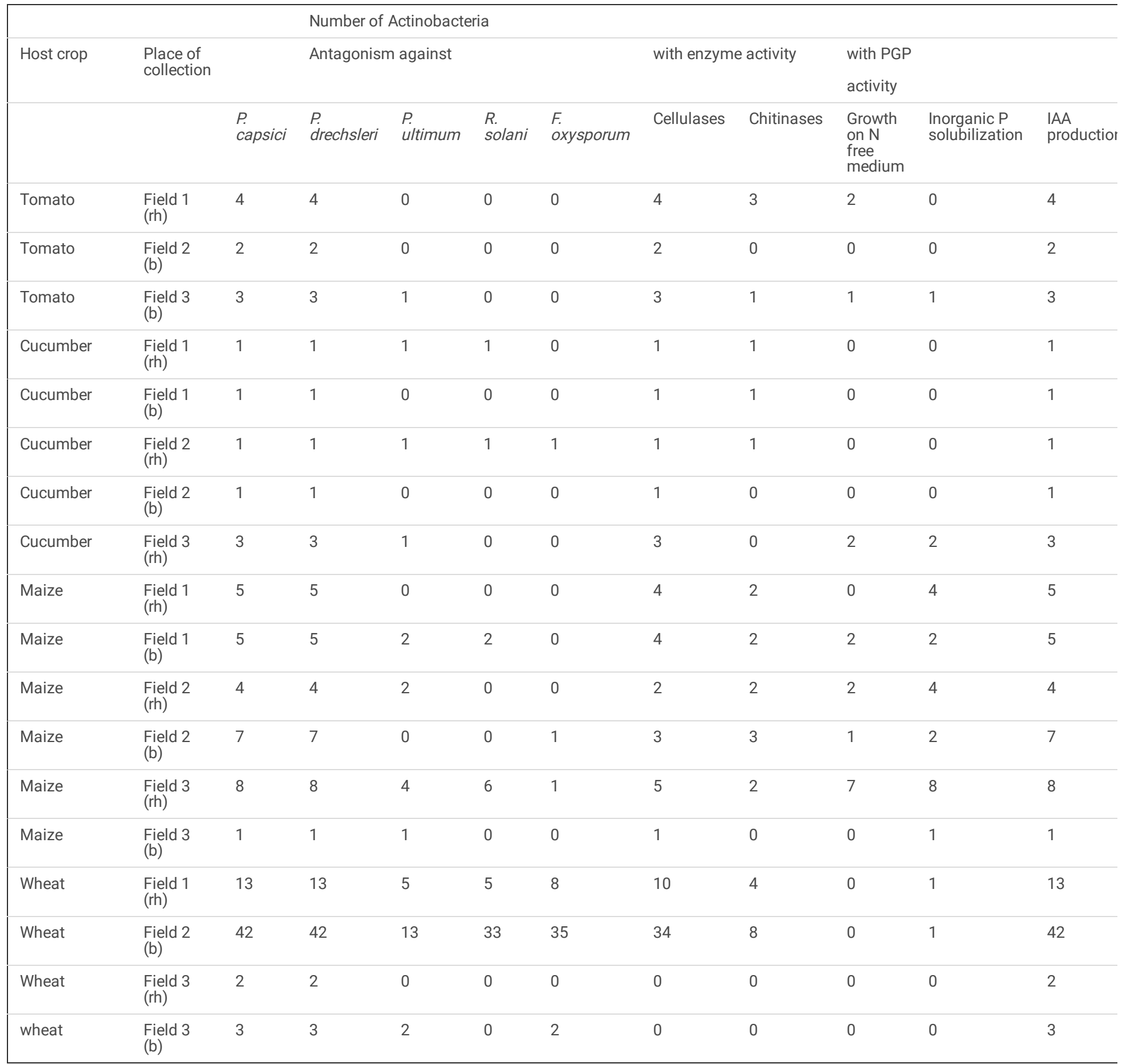

Table 3. Antagonistic activity against plant phytopathogens, hydrolytic enzyme activity, PGP properties and genotypic characterization of 13 selected antagonistic isolates 
Isolate Host crop Antagonistic activity (\%)

PGPR activity

\begin{tabular}{|c|c|c|c|c|c|c|c|c|c|c|c|c|}
\hline & & $\begin{array}{l}\text { P. } \\
\text { capsici }\end{array}$ & $\begin{array}{l}\text { P. } \\
\text { drechsleri }\end{array}$ & $\begin{array}{l}P \\
\text { ultimum }\end{array}$ & $\begin{array}{l}R . \\
\text { solani }\end{array}$ & $\begin{array}{l}\text { F. } \\
\text { oxysporum }\end{array}$ & Cellulases & Chitinases & $\begin{array}{l}\text { Siderophore } \\
\text { production }\end{array}$ & $\begin{array}{l}\text { Growth } \\
\text { on N } \\
\text { free } \\
\text { medium }\end{array}$ & $\begin{array}{l}\text { Inorganic } P \\
\text { solubilization }\end{array}$ & \\
\hline 407 & tomato & 100 & 33 & - & - & - & 3 & 1.8 & + & + & - & $\begin{array}{l}A \\
4 \vdots \\
(A\end{array}$ \\
\hline 405 & tomato & 20 & 63 & - & - & - & 4.7 & 1.1 & ++ & + & - & $\begin{array}{l}A \\
4 \vdots \\
(A\end{array}$ \\
\hline 432 & tomato & 20 & 63 & - & - & - & 4.7 & - & - & - & - & $\begin{array}{l}S . \\
5 \\
(A\end{array}$ \\
\hline 515 & tomato & 100 & 50 & 60 & - & - & 2.9 & 1.2 & - & - & - & $\begin{array}{l}S . \\
N \\
(A\end{array}$ \\
\hline 3637 & cucumber & 100 & 55 & - & - & - & 2.5 & - & - & - & + & $\begin{array}{l}S . \\
\text { B- } \\
(A\end{array}$ \\
\hline 3415 & cucumber & 20 & 60 & 50 & - & - & 1.3 & - & + & + & + & $\begin{array}{l}A \\
r c \\
\mathrm{M}\end{array}$ \\
\hline 3513 & cucumber & 95 & 53 & - & - & - & 4.3 & - & - & + & - & $\begin{array}{l}A \\
r c \\
M\end{array}$ \\
\hline 1119 & maize & 30 & 50 & 85 & - & - & - & - & ++ & + & + & $\begin{array}{l}A . \\
\mathrm{J}( \\
(\Lambda\end{array}$ \\
\hline 1118 & maize & 30 & 48 & 86 & - & - & - & - & - & + & + & $\begin{array}{l}A . \\
\mathrm{Ul} \\
\text { ([ }\end{array}$ \\
\hline 1331 & maize & 40 & 41 & 43 & 60 & - & - & - & + & + & + & $\begin{array}{l}A \\
4 \vdots \\
(A\end{array}$ \\
\hline 1317 & maize & 30 & 30 & - & 60 & - & 2 & - & - & + & + & $\begin{array}{l}S . \\
\mathrm{N} \\
(\mathrm{J}\end{array}$ \\
\hline 614 & wheat & 95 & 60 & 100 & 67 & 84 & - & 1.3 & ++ & - & - & $\begin{array}{l}S . \\
\mathrm{N} \\
(\mathrm{J}\end{array}$ \\
\hline 615 & wheat & 100 & 54 & 100 & 69 & 63 & 1.1 & - & ++ & - & - & $\begin{array}{l}S . \\
N \\
(J\end{array}$ \\
\hline
\end{tabular}

"+" producing or growth, "-" non- producing or no growth

Table 4. Influence of selected antagonistic isolates on cucumber germination and growth parameters relative to untreated control in greenhouse conditions 


\begin{tabular}{|lllll|}
\hline \multicolumn{4}{|l}{ Changes compared to untreated control (\%) } & \\
\hline shoot dry weight & shoot fresh weight & plant height & germination & Isolate \\
\hline 17 & & & & \\
\hline 25 & 25 & 19 & 0 & 3513 \\
\hline-28 & 43 & 28 & 0 & 1119 \\
\hline-15 & -40 & -29 & $35-$ & 1118 \\
-34 & -50 & -20 & $80-$ & 3415 \\
\hline-65 & -47 & -51 & $60-$ & 1331 \\
\hline- & -69 & -66 & $80-$ & 407 \\
\hline-10 & - & - & $100-$ & 405 \\
\hline-8 & -10 & -6 & 0 & 3637 \\
\hline 9 & -16 & -1 & 0 & 1317 \\
\hline 0 & 11 & 12 & 0 & 432 \\
\hline 0 & 1 & 9 & 0 & 614 \\
\hline 20 & 4 & 0 & 0 & 515 \\
\hline
\end{tabular}

Table 5. Effect of strain 1119 on cucumber fruit yield and quality compared to untreated control in commercial greenhouse conditions

\begin{tabular}{|llllll|}
\hline Treatment & $\begin{array}{l}\text { Fruit yield } \\
\text { ton } / 1000 \mathrm{~m}^{2}\end{array}$ & $\begin{array}{l}\text { Fruit dry weight } \\
\%\end{array}$ & $\begin{array}{l}\text { Total soluble sugar } \\
\mathrm{g} / 100 \mathrm{gFW}\end{array}$ & $\begin{array}{l}\text { Nitrate content } \\
\mathrm{mg} / 100 \mathrm{gFW}\end{array}$ & $\begin{array}{l}\text { Sensory test (overall acceptance) } \\
\text { compared to control }\end{array}$ \\
\hline control & 3.9 & 6.72 & 1.76 & 30.48 & \\
\hline strain 1119 & $4.7^{*}$ & $4.6 *$ & 1.51 & $9.58^{*}$ & NS \\
\hline
\end{tabular}

Values are the means (averaged from four replicates) \pm SE. The values marked with an asterisk are significantly different from the control $P<0.05$

Table 6. Effect of strain 1119 on cucumber leaf protein, antioxidant enzymes activity and MDA and $\mathrm{H}_{2} \mathrm{O}_{2}$ content compared to untreated control in commercial greenhouse conditions

\begin{tabular}{|lllllll|}
\hline Treatment & $\begin{array}{l}\text { Leaf protein } \\
\text { mg/g FW }\end{array}$ & $\begin{array}{l}\text { CAT } \\
\text { U/mg protein }\end{array}$ & $\begin{array}{l}\text { POX } \\
\text { U/mg protein }\end{array}$ & $\begin{array}{l}\text { APX } \\
\text { U/mg protein }\end{array}$ & $\begin{array}{l}\mathrm{H}_{2} \mathrm{O}_{2} \text { content } \\
\mu \mathrm{M} / \mathrm{g} \mathrm{FW}\end{array}$ & $\begin{array}{l}\text { MDA } \\
\mathrm{nmol} / \mathrm{g}\end{array}$ \\
& & & & & & \\
control & 2.26 & 1.29 & 3.96 & 1.57 & 5.00 & 1.03 \\
strain 1119 & 2.24 & $3.28^{*}$ & $4.94^{*}$ & $2.42^{*}$ & $2.24^{*}$ & $0.65^{\star}$ \\
\hline
\end{tabular}

Values are the means (averaged from four replicates) \pm SE. The values marked with an asterisk are significantly different from the control $P<0.05$

\section{Figures}




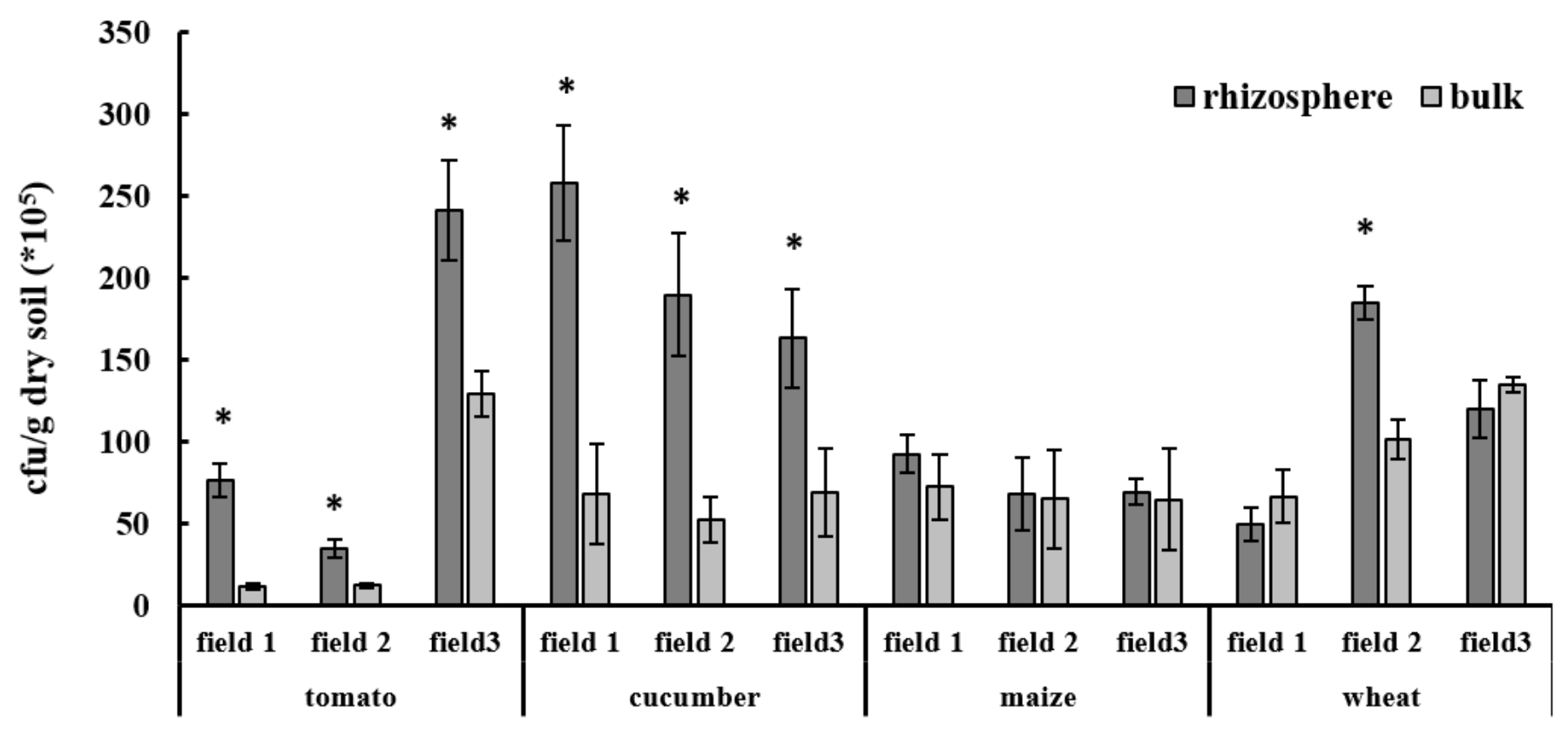

Figure 1

The abundance of culturable bacteria isolated from bulk and rhizosphere soil of different fields of tomato, cucumber, maize, and wheat. Data represent the mean values $\pm \mathrm{SE}$ of three samples. The values related to rhizosphere marked with an asterisk are significantly different from the bulk $\mathrm{P}<0.05$

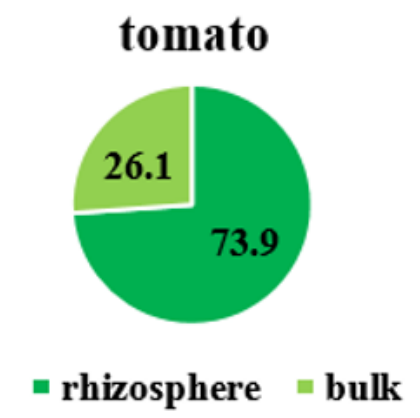

cucumber

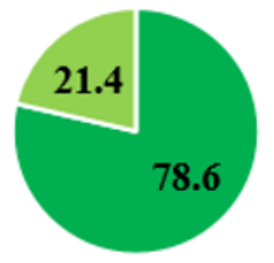

" rhizosphere "bulk

\section{maize}

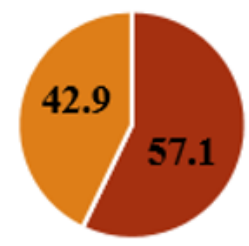

" rhizosphere "bulk

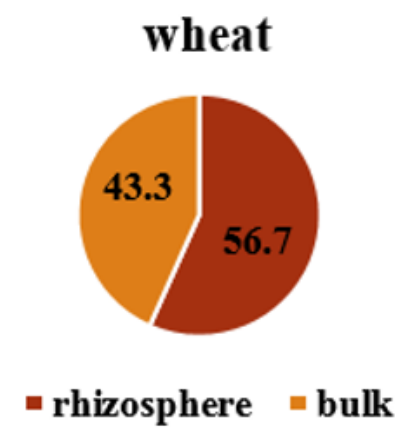

Figure 2

The percentage of colonies isolated from bulk and rhizosphere soil of different crops a) tomato, b) cucumber, c) maize and d) wheat 


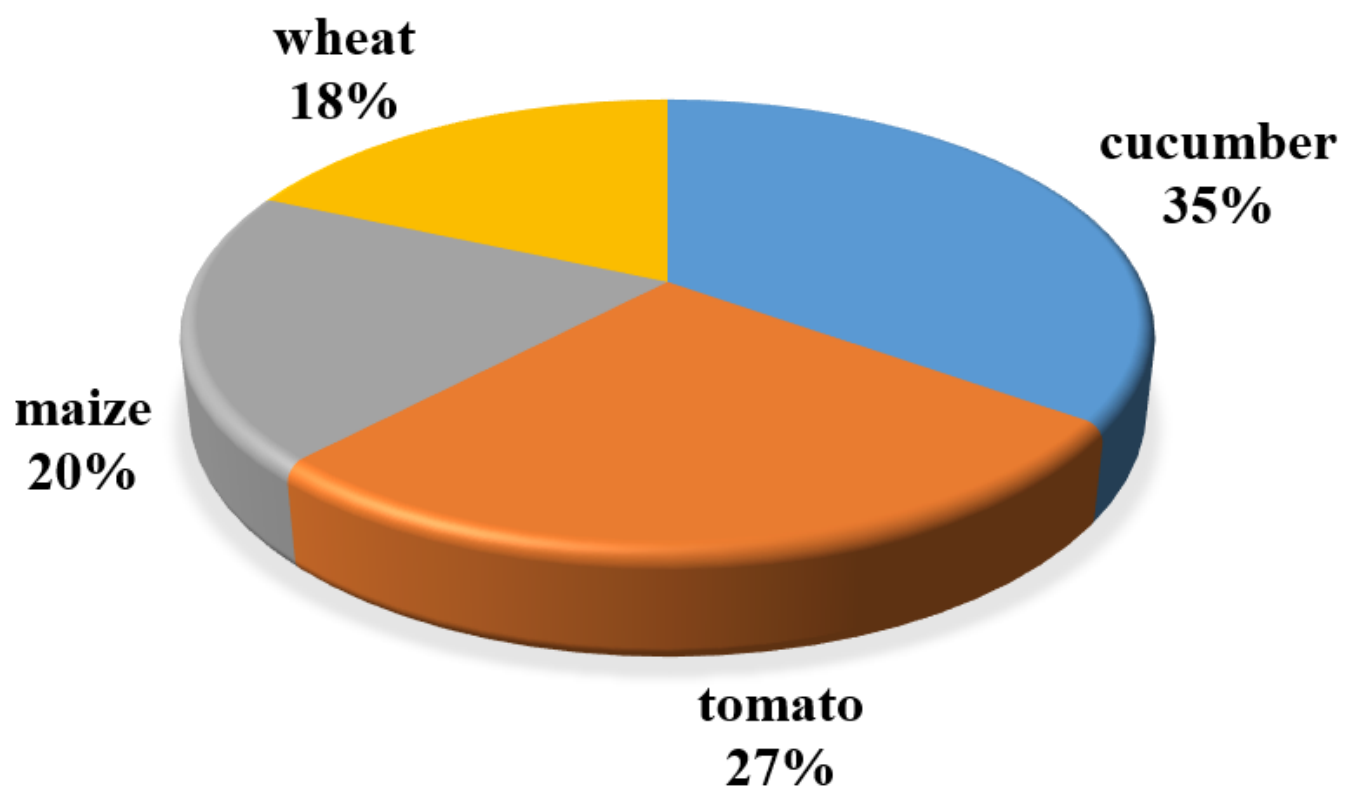

Figure 3

The portions of each crop from Actinobacteria isolates.

\section{$\mathbf{a}$}
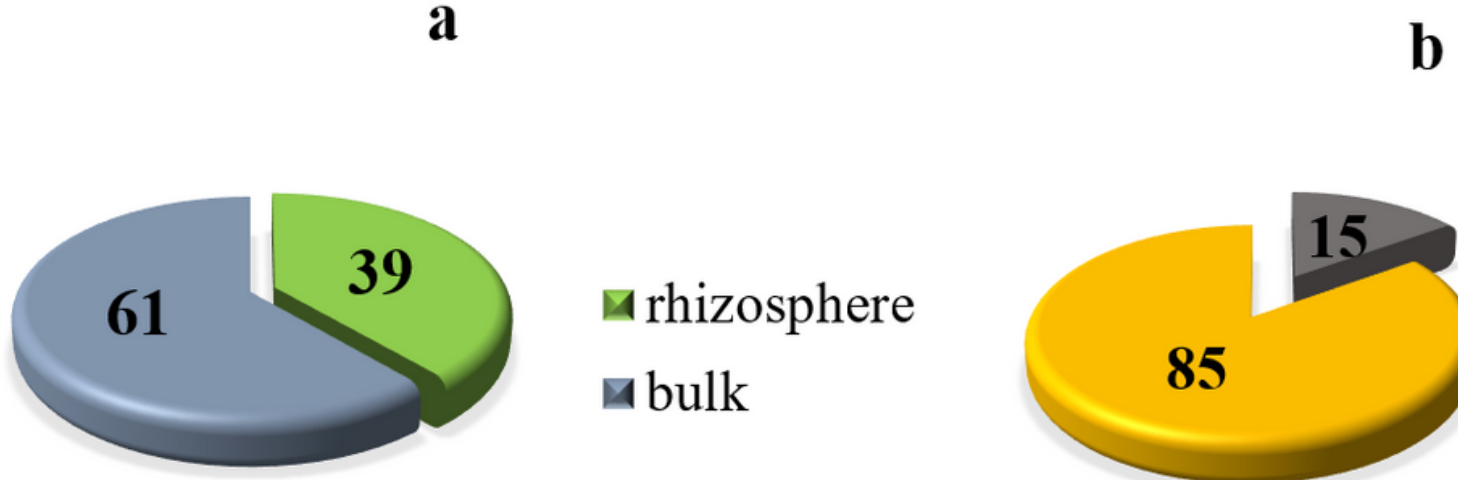

Ahizosphere abulk

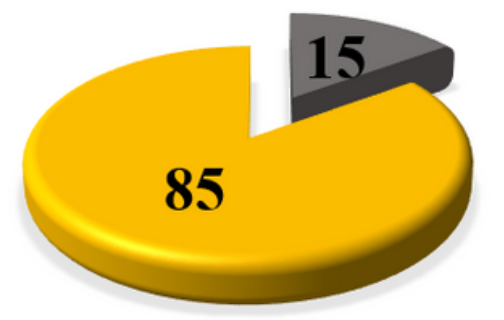

$\triangle$ monocot

Figure 4

The percentage of antagonistic actinomycetes isolated from a) bulk and rhizosphere soil of b) monocots and dicots crops 


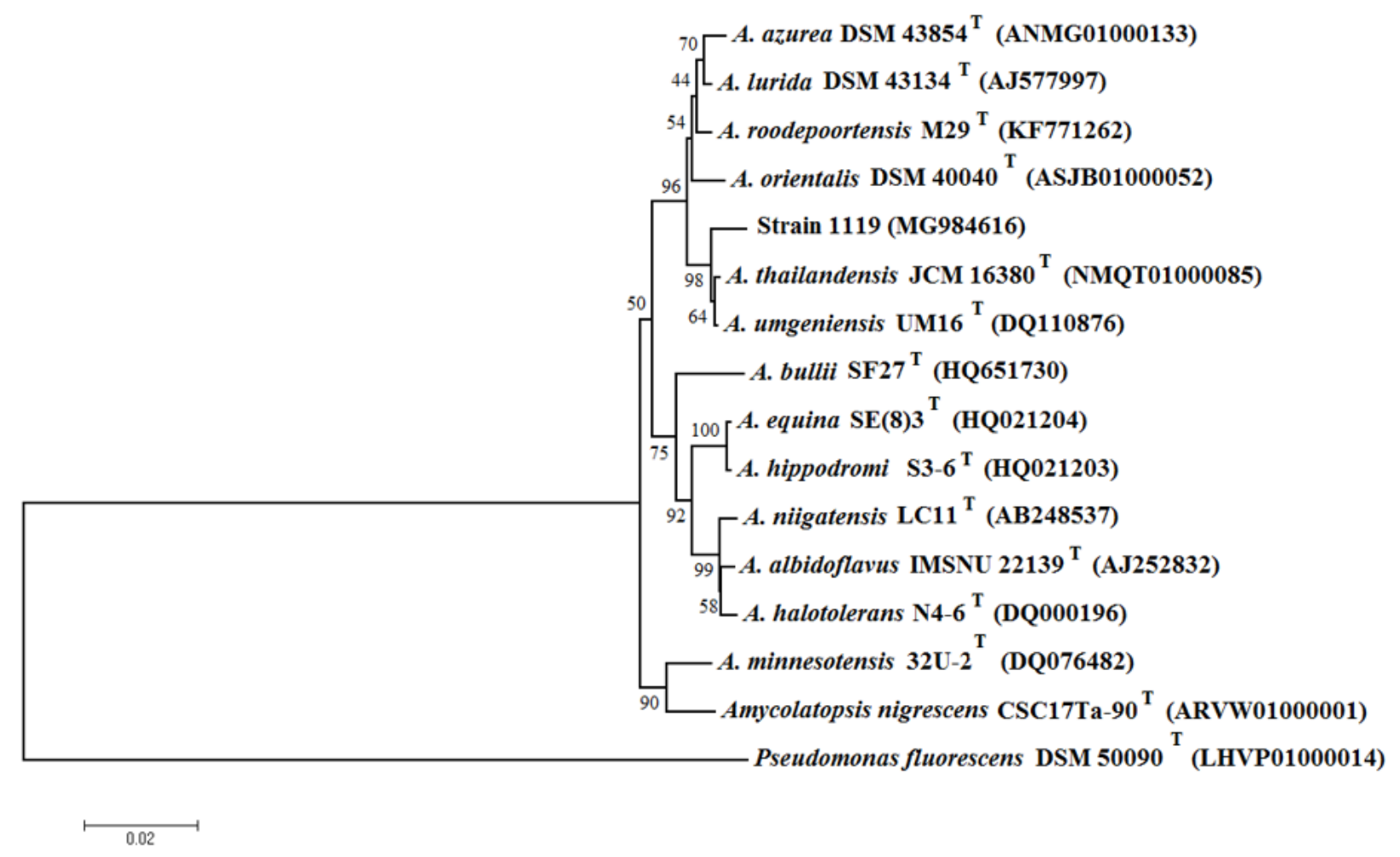

Figure 5

Phylogenetic tree based on almost complete 16S rRNA gene sequences of Amycolatopsis strain 1119. Tree was calculated using neighbor-joining method illustrating the taxonomic position of the strain with related species. Accession numbers of the sequences are given in parentheses. The sequences of Pseudomonas fluorescens DSM 50090T (LHVP01000014) was used as outgroup. Bootstrap values are based on 1000 resampling and shown at the branching points. Bar indicates 0.02 substitutions per nucleotide position

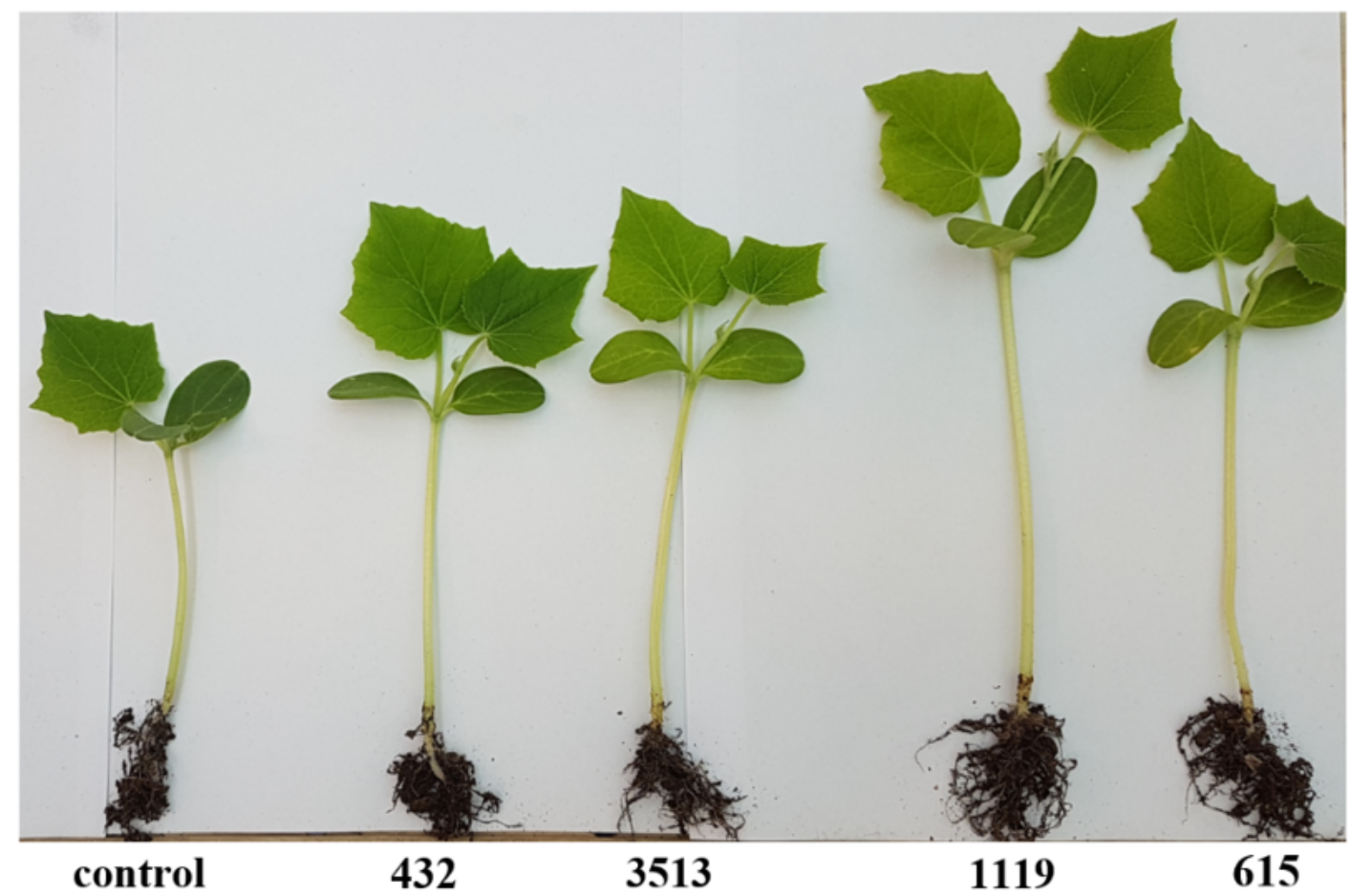

Figure 6

The effect of superior PGP strains $(432,3513,1119$ and 615$)$ on the growth of cucumber seedling 


\section{disease incidence}

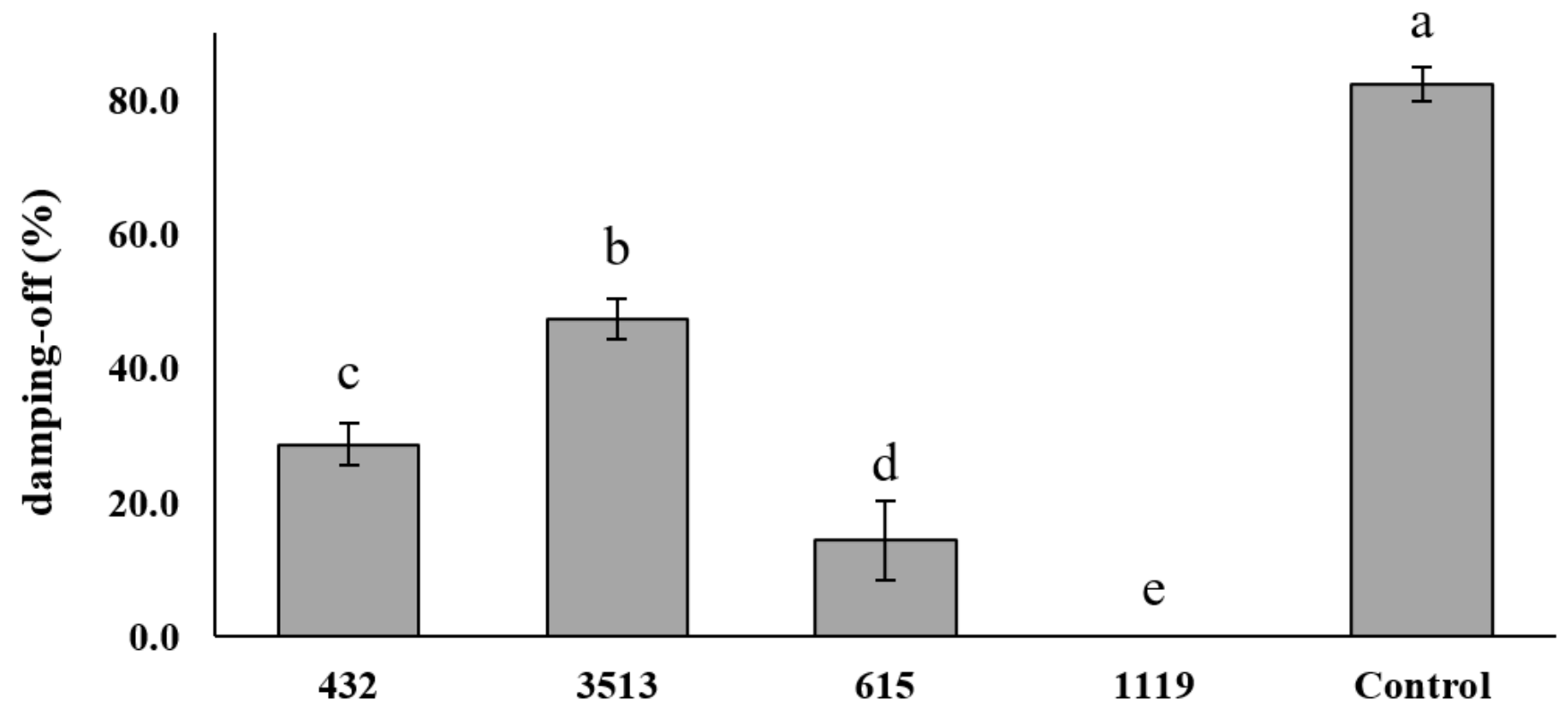

Figure 7

Biocontrol of P. capsici damping-off of cucumber seedlings by superior PGP strains. Data represent the mean values \pm SE of 8 replicates. Same letters represent non-significant difference according to Duncan's Multiple Range Test $(P<0.05)$

a) shoot fresh weight

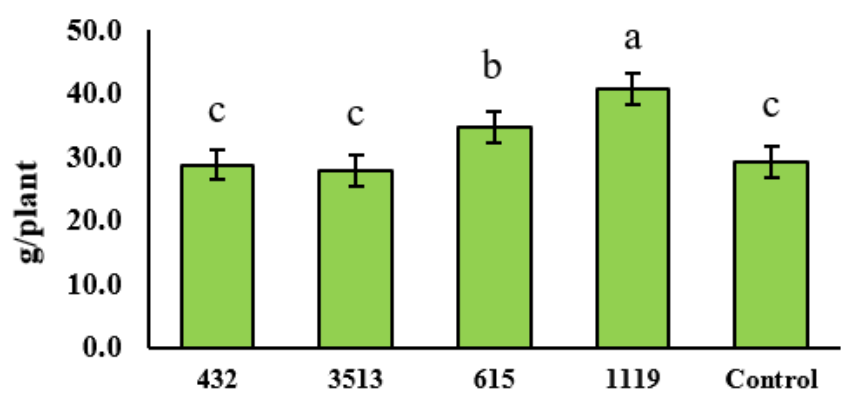

c) root fresh weight

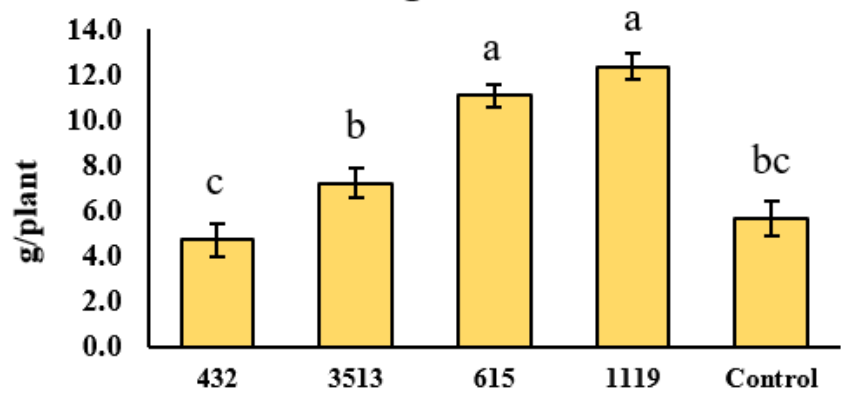

b) shoot dry weight

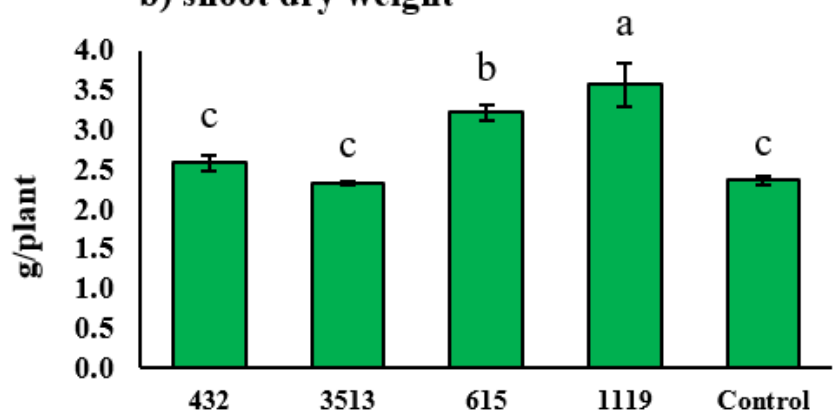

d) root dry weight

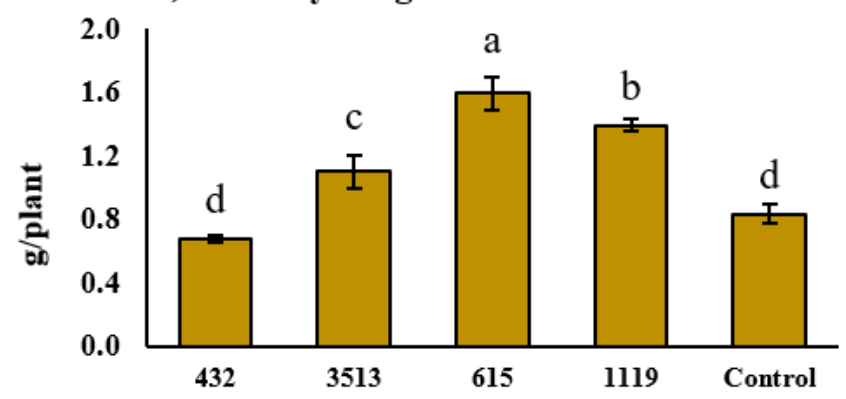

Figure 8

The effect of superior PGP strains on the growth parameters of cucumber seedlings a: shoot fresh weight; b: shoot dry weight; c: root fresh weight and d: root dry weight. Data represent the mean values \pm SE of 8 replicates. Same letters represent non-significant difference according to Duncan's Multiple Range Test $(P<0.05)$ 


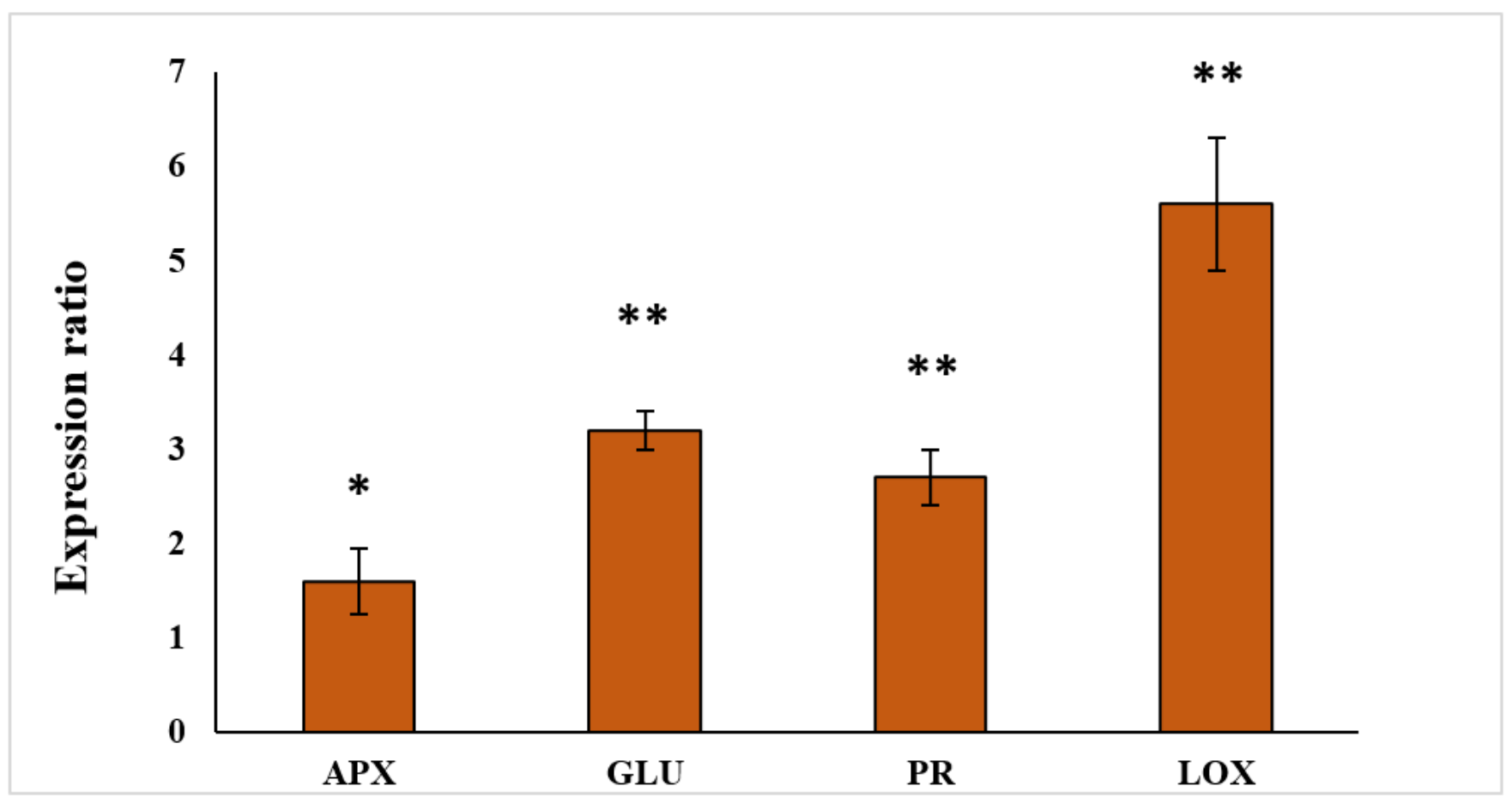

Figure 9

Transcriptional responses of defense related genes of cucumber leaves to bacterial treatment (strain 1119) versus internal control (elongation factor, EF) 15 days after treatment. Untreated plants were considered as control. The values marked with one or two asterisks are significantly different from control at $\mathrm{P}<$ 0.05 and $P<0.01$ respectively 